\title{
11. CALCAREOUS NANNOFOSSIL BIOSTRATIGRAPHY OF LEG 127 IN THE JAPAN SEA ${ }^{1}$
}

\author{
Atiur Rahman ${ }^{2}$
}

\begin{abstract}
Calcareous nannofossils were studied by light microscopy in Neogene sedimentary rocks recovered at four sites of the Ocean Drilling Program Leg 127 in the Japan Sea. Nannofossils occur sporadically at all sites, and allow recognition of seven zones and two subzones; four zones in the Holocene to the uppermost Pliocene, and three zones and two subzones in the middle to lower Miocene.

Forty-eight nannofossil species are recognized in 95 of the 808 irregularly-spaced samples taken from all the sites. The nannofossil assemblages in the Miocene are more diverse than those in the Holocene to Pliocene sedimentary interval. The greater diversity and the presence of warm-water taxa, such as Sphenolithus and discoasters in the upper lower Miocene to lower middle Miocene, suggest a relatively warm and stable surface-water condition, attributed to an increased supply of warm water from the subtropical western Pacific Ocean.

Site 797 in the southern part of the Yamato Basin contains the most complete and the oldest nannofossil record so far reported from the Japan Sea. The lowermost nannofossil zone at this site, the Helicosphaera ampliaperta Zone (15.7-18.4 Ma) gives a minimum age for the Yamato Basin. This age range predates rotation of southwest Japan, an event previously believed to be caused by the opening of the Japan Sea.
\end{abstract}

\section{INTRODUCTION}

The Japan Sea in the northwestern Pacific region is one of the most extensively studied marginal seas, consisting of several deep basins (Japan Basin, Yamato Basin, Tsushima Basin) separated by ridges of continental crust (Tamaki, 1988). The opening of the Japan Sea is most often attributed to a rapid clockwise rotation of southwest Japan and a counterclockwise rotation of northeast Japan in the middle Miocene (Otofuji et al., 1985a, 1985b; Otofuji and Matsuda, 1987; Tatsumi et al., 1989). The magnetic lineations in the Japan Sea are poorly developed and do not allow testing of the age of spreading (Kobayashi, 1985; Tamaki, 1988).

The different stages of tectonic, sedimentary, and oceanographic development of the Japan Sea are recorded by a thick sequence of sedimentary rocks that had never been fully recovered prior to the recent Ocean Drilling Program (ODP) Leg 127. The Deep Sea Drilling Project (DSDP) Leg 31 only recovered upper Neogene sediment, with nannofossils mostly from the Quaternary (Ellis, 1975; Karig, Ingle, et al., 1975). On ODP Leg 128 we cored the Neogene sequence and recovered nannofossils in the Holocene, Pliocene, and middle Miocene (Muza, this volume).

Leg 127, one of the two ODP legs in the Japan Sea, drilled at two sites (794 and 797) in the Yamato Basin and two sites (795 and 796) in the Japan Basin (Fig. 1). The primary objectives of Leg 127 were to determine the nature and age of the basement rocks, the tectonic style of deformation, and to reveal the structural, sedimentary, and paleoceanographic history of the Japan Sea. Ten holes at four sites recovered a thick sequence of Holocene to lower Miocene sedimentary rocks and penetrated an underlying acoustic basement of interbedded volcanic and sedimentary rocks. The sedimentary rocks include volcaniclastic and clastic sandstones, oozes, and hemipelagic muds, claystones, and silty claystones rich in siliceous microfossils (Tamaki, Pisciotto, Allan, et al., 1990). Most of these sedimentary rocks contain little calcium carbonate because of high terrigenous influx and carbonate dissolution resulting in a shallow calcite compensation depth (CCD), which is presently at $2000 \mathrm{~m}$ (Ujiié and Ichikura, 1973).

'Pisciotto, K. A., Ingle, J. C., Jr., von Breymann, M. T., Barron, J., et al., 1992. Proc. ODP, Sci. Results, 127/128, Pt. 1: College Station, TX (Ocean Drilling Program).

${ }^{2}$ Department of Geology and Geophysics, University of Utah, Salt Lake City, Utah 84112-1183, U.S.A.
Well to poorly preserved nannofossils occur sporadically in the Holocene to uppermost Pliocene, and in the middle to lower Miocene of the sedimentary sequence cored by Leg 127 . Nannofossils are the best documented of all microfossil groups below the opal-A/opal-CT Boundary in the middle and uppermost lower Miocene of the Japan Sea and provide important age control to estimate the sedimentation rates and to constrain the age of basement rocks (Leg 127 Shipboard Scientific Party, 1989; Tamaki, Pisciotto, Allan, et al., 1990).

Nannofossil assemblages are more diverse in the lower middle Miocene to upper lower Miocene and less diverse in the Holocene to upper Pliocene. The most complete and the oldest record of nannofossils in the Japan Sea is found at Site 797 in the southern part of the Yamato Basin. This report discusses the nannofossil biostratigraphy in the sedimentary sequence of the Japan Sea, and states the major implications of the results.

\section{SAMPLES AND METHODS}

Each core of sedimentary rock was sampled at irregular intervals, depending on the recovery, the potential for locating nannofossil events (FO, first occurrence; $\mathrm{LO}$, last occurrence), the presence of relatively undisturbed core intervals, and on the calcium carbonate content. Smear slides were prepared following the technique outlined in Rahman and Roth (1989). Samples were prepared for observation under scanning electron microscope by a centrifuging method (PerchNielsen, 1985). Most work was done by transmitted-light microscopy, but the scanning electron microscope was used to observe small taxa that are difficult to identify under the light microscope.

After counting 15-20 randomly selected fields of view under the light microscope (at $1560 \times$ magnification), the total number of nannofossils was expressed by using one of the following semiquantitative categories: $\mathrm{A}=$ abundant, containing 10 or more specimens per field of view; $\mathrm{C}=$ common, containing $1-9$ specimens per field of view; $\mathrm{M}=$ many, containing less than 1 specimen per field, but more than 1 specimen in 10 fields of view; $\mathrm{F}=$ few, containing 1 specimen in 10 fields of view; $\mathrm{R}=$ rare, containing 1 specimen in more than 10 fields of view. Smear slides were called barren if no nannofossil was observed in about 100 fields of view. Each smear slide containing nannofossils was observed under light microscope in randomly selected traverses for $2-4 \mathrm{hr}$. The relative abundance of each nannofossil taxon was noted by using categories (A, C, M, F, R) just defined. Samples from each site were investigated for the presence and relative 


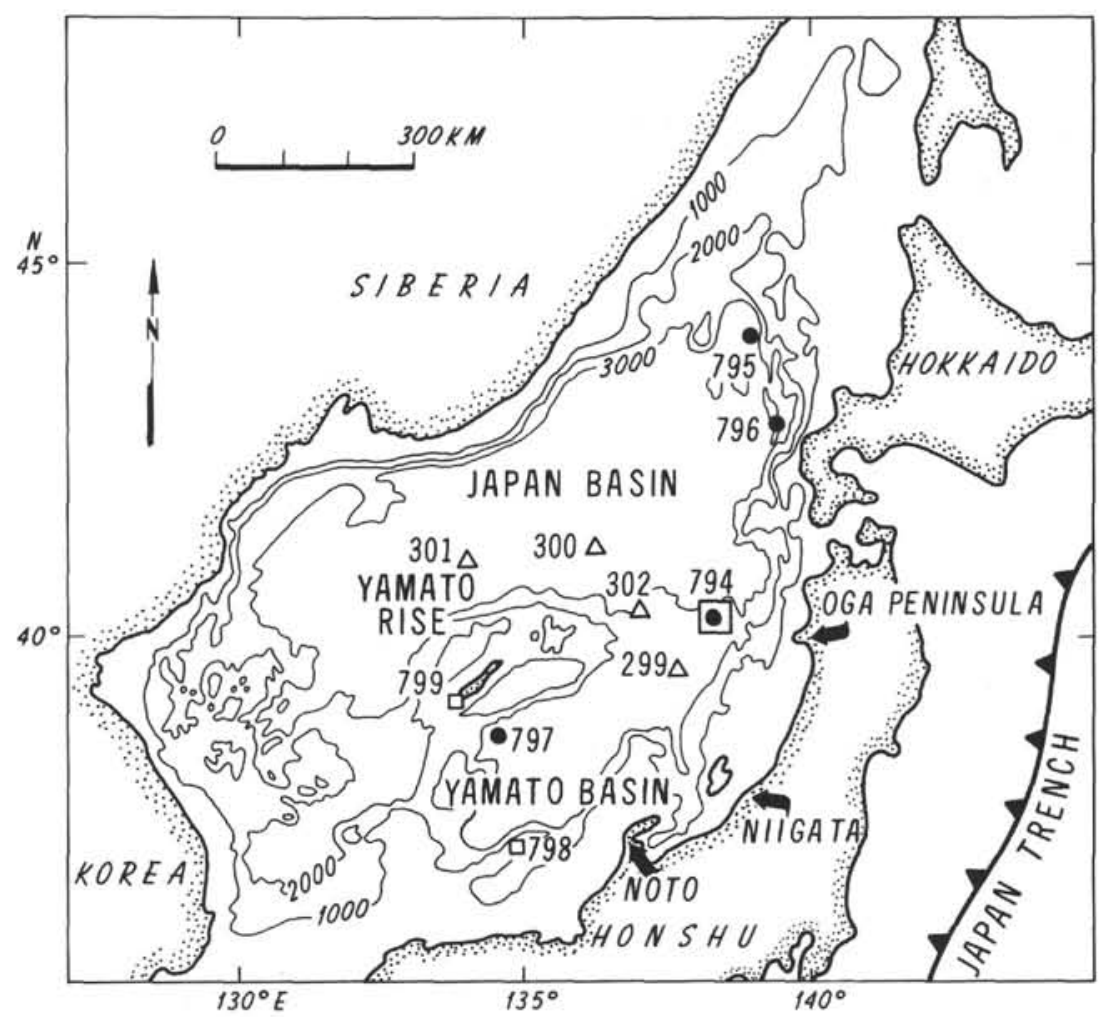

Figure 1. Bathymetric map of the Japan Sea showing the locations of Leg 127 sites (794-797) as filled circles, Leg 128 sites (794-799) as squares, and DSDP Leg 31 sites (299-302) as triangles. Contour values are in meters. Toothed line represents Japan Trench. Site 794 was drilled during Legs 127 and 128.

abundance of taxa as listed in Appendix A, where taxonomic concepts used in this study are also briefly noted.

The state of nannofossil preservation was based on light microscopic observation of all species, rather than relying heavily on delicate taxa, such as Syracosphaera, Pontosphaera, Rhabdosphaera, Discosphaera, andOlitothus (Roth, 1974). This is because the delicate taxa prefer relatively warm surface water (Roche et al., 1975; Roth and Coulbourn, 1982), and may have been environmentally excluded from the Japan Sea, where present surface water is cool. The following preservational categories were used:

$\mathrm{E}=$ excellent - outer margin of the placoliths are smooth without any crenulation, intact specimens of delicate species (Syracosphaera, Pontosphaera) may be present, no overgrowth.

E-1 = slightly etched-indicated by broken specimens, crenulated margins, fragments of delicate species, and isolated shields of some coccoliths.

E-2 = moderately etched - most coccoliths show crenulated margins, delicate bridges and central structures are mostly dissolved, and broken specimens and separate shields are common.

E-3 = strongly etched-most nannofossils are fragmented, coccoliths show crenulated margins, resistant taxa (Coccolithus, Discoaster, Reticulofenestra) are differentially enriched.

O-1 = slight overgrowth-the shields or central structures of some coccoliths show slight overgrowth, and slight thickening of the arms and central knobs of discoasters.

$\mathrm{O}-2$ = moderate overgrowth-most of the coccoliths and discoasters are overgrown but still mostly recognizable.

$\mathrm{O}-3$ = strong overgrowth-discoasters are overgrown beyond recognition to the species level, other coccoliths are difficult to identify.
Preservation was called excellent (E) if nannofossils showed no evidence of etching or overgrowth, good $(G)$ if nannofossils were only slightly etched and/ or overgrown, moderate (M) if nannofossils were moderately etched and/ or overgrown, and poor ( $\mathrm{P}$ ) if nannofossils were strongly etched and/ or overgrown.

\section{CALCAREOUS NANNOFOSSIL EVENTS AND ZONES}

The nannofossil zones used in this study for the Holocene to the uppermost Pliocene are adopted from zonations suggested earlier (Hay et al., 1967; Gartner, 1969; Martini, 1971; Bukry, 1973; Rahman and Roth, 1989) with few modifications as shown in Figure 2. This figure also compares Holocene to upper Pliocene nannofossil zones of different authors with the zones used in this study. The middle Pliocene to Miocene zones are adopted from Okada and Bukry (1980). Table 1 shows all the Neogene nannofossil zones, subzones, and events and their ages used in this study. The ages of the nannofossil events are taken from Thierstein et al. (1977), Backman and Shackleton (1983), Barron et al. (1985a, b), Berggren et al. (1985), Rahman and Roth (1989), and Backman et al. (1990). The bases of the Pleistocene, Pliocene, upper Miocene, and middle Miocene are approximated by the FO's of Gephyrocapsa caribbeanica (1.68 Ma), Ceratolithus acutus (4.9 Ma), Discoaster hamatus (10.5 Ma), and Calcidiscus macintyrei (15.7 Ma), respectively. The age estimates of these events most closely correspond to the respective epoch and stage boundaries of the time scale of Berggren et al. (1985).

Nannofossil zones and subzones in the Japan Sea are recognizable in two sedimentary intervals, one in the Holocene to uppermost Pliocene, and the other in the middle to lower Miocene. The precise 


\begin{tabular}{|c|c|c|c|c|c|c|c|c|c|}
\hline $\begin{array}{l}\text { Age } \\
\text { (Ma) }\end{array}$ & \begin{tabular}{|l|} 
Period \\
Epoch
\end{tabular} & Hay et al. (1967) & Gartner (1969) & Martini (1971) & Bukry (1973) & Gartner (1977) & Bukry (1978) & \begin{tabular}{|c|} 
Rahman and Roth \\
(1989)
\end{tabular} & This study \\
\hline \multirow{5}{*}{$1.00-$} & \multirow{5}{*}{ 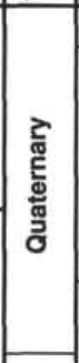 } & E. huxleyi & E. huxleyi & E. huxleyi & E. huxleyi & $\begin{array}{c}\text { E. huxleyi acme and } \\
\text { E. huxdeyi }\end{array}$ & E. huxleyi & E. huxleyi & E. huxleyi \\
\hline & & \multirow{3}{*}{ G. oceanica } & Gephyrocapsa & G. oceanica & \multirow{3}{*}{ G. oceanica } & G. oceanica & C. cristatus & G. oceanica & Gephyrocapsa \\
\hline & & & \multirow{4}{*}{ P. lacunosa } & \multirow{4}{*}{ P. lacunosa } & & P. lacunosa & \multirow[t]{2}{*}{ E. ovata } & \multirow[t]{2}{*}{ U. sibogae } & \multirow[t]{2}{*}{ U. sibogae } \\
\hline & & & & & & Small Gephyrocapsa & & & \\
\hline & & \multirow[t]{2}{*}{ G. caribbeanica } & & & G. caribbeanica & \multirow{2}{*}{ C. macintyrei } & G. caribbeanica & $\begin{array}{l}\text { G.cariboeance } \\
\text { c. macinyred }\end{array}$ & G. caribbeanica \\
\hline \multirow{3}{*}{$2.00-$} & \multirow{3}{*}{ 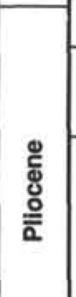 } & & & & E. annula & & E. annula & P. lacunosa & P. lacunosa \\
\hline & & $\begin{array}{l}\text { D. brouweri } \\
\text { D. extensus }\end{array}$ & D. brouweri & D. brouweri & C. macintyrei & D. brouweri & C. macintyrei & D. brouweri & D. brouweri \\
\hline & & D. surculus & D. surculus & D. pentaradiatus & D. pentaradiatus & & D. pentaradiatus & D. pentaradiatus & D. pentaradiatus \\
\hline
\end{tabular}

Figure 2. Calcareous nannofossil zones and subzones between the Holocene and upper Pliocene. Zonal and subzonal boundaries are based on ages presented in Table 1. Ages of the events not presented in Table 1 are taken from Gartner (1977) and Rahman and Roth (1989).

Table 1. Calcareous nannofossil zones and subzones for the Neogene.

\begin{tabular}{|c|c|c|c|c|c|}
\hline $\begin{array}{l}\text { Period } \\
\text { /Epoch }\end{array}$ & $\begin{array}{c}\text { Zone } \\
\text { /Subzone }\end{array}$ & Event & Species & $\begin{array}{l}\text { Age } \\
\text { (Ma) }\end{array}$ & Reference $^{a}$ \\
\hline \multirow[t]{4}{*}{ Quaternary } & E. huxleyi (CN15) & FO & E. huxleyi & 0.27 & 1 \\
\hline & Gephyrocapsa (CN14b) & LO & P. lacunosa & 0.46 & 1 \\
\hline & U. sibogae (CN14a) & FO & G. oceanica & 1.35 & 2 \\
\hline & G. caribbeanica $(\mathrm{CN} 13 \mathrm{~b})$ & FO & G. caribbeanica & 1.68 & 2 \\
\hline \multirow[t]{6}{*}{ Pliocene } & P. lacunosa (CN13a) & LO & D. brouweri & 1.89 & 3 \\
\hline & D. brouweri (CN12) & LO & S. neoabies & 3.51 & 2 \\
\hline & R. pseudoumbilica (CN11) & LO & C. primus & 4.40 & 4 \\
\hline & C. tricomiculatus (CN10) & & & & \\
\hline & C. rugosus (CN1Oc) & LO & C. acutus & 4.60 & 3 \\
\hline & C. acutus (CN10b) & FO & C. acutus & 4.90 & 5 \\
\hline \multirow[t]{14}{*}{ Miocene } & T. rugosus (CNIOa) & LO & D. quinqueramus & 5.00 & 5 \\
\hline & D. quinqueramus (CN9) & FO & D. berggrenii & 8.10 & 2 \\
\hline & D. neohamatus (CN8) & LO & D. hamatus & 8.70 & 5 \\
\hline & D. hamatus (CN7) & FO & D. hamatus & 10.5 & 5 \\
\hline & C. coalitus (CN6) & FO & C. coalitus & 11.1 & 5 \\
\hline & D. exilis (CN5) & & & & \\
\hline & D. kugleri (CN5b) & Lo & C. floridanus & 13.1 & 5 \\
\hline & C. miopelagicus (CNSa) & LO & S. heteromorphus & 14.0 & 6 \\
\hline & $S$, heteromorphus (CN4) & FO & C. macintyrei & 15.7 & 6 \\
\hline & H. ampliaperta $(\mathrm{CN} 3)$ & FO & S. heteromorphus & 18.4 & 5 \\
\hline & S. belemnos $(\mathrm{CN} 2)$ & FO & S. belemnos & 20.0 & 5 \\
\hline & T. carinatus (CN1) & & & & \\
\hline & D. drugï (CNIc) & FO & D. drugii & 23.2 & 4 \\
\hline & D. deflandrei $(\mathrm{CN} I \mathrm{~b})$ & Acme & C. abisectus & 23.7 & 4 \\
\hline
\end{tabular}

Note: First and last occurrences of marker species defining the base of the biostratigraphic units are indicated. The ages of the datum events are taken from different sources as indicated. Code numbers of zones and subzones from Okada and Bukry (1980) are shown in parentheses.

"1. Thierstein et al. (1977); 2, Rahman and Roth (1989); 3, Backman and Shackleton (1983); 4, Berggren et al. (1985); 5, Backman et al. (1990); 6, Barron et al. (1985a).

position of some events within these intervals are unknown because of sporadic occurrence, absence, or scarcity of marker species. Discussion of events, zones, and subzones in this study is therefore restricted to these two intervals.

In this study, the nannofossil zones between the Holocene and the upper Pliocene (Fig. 2) utilized first and last occurrence events, all of them except the FO of Gephyrocapsa oceanica dated at 1.35 Ma were widely used in previous studies. This age, based on interpolation between radiometrically dated tephra layers and a modified species concept (Rahman and Roth, 1989), is also supported by nannofossil data at DSDP Site 533 in the Atlantic Ocean (Rahman, in press).
Berggren et al. (1985) reported the FO of $G$. oceanica at $1.68 \mathrm{Ma}$. I follow Rahman and Roth (1989) for the age estimate of the FO and the modified species concept of $G$. oceanica. This allows the recognition of the interval between the FO's of $G$. oceanica and $G$. caribbeanica, and also changes the duration of zones that use the FO of $G$. oceanica as a marker.

The early estimate of the age of the FO of Gephyrocapsa oceanica (1.68 Ma, Berggren et al., 1985) is close to or similar to the age estimate for the FO of Gephyrocapsa caribbeanica. Takayama and Sato (1987) estimate the age of the FO of G. caribbeanica at $1.66 \mathrm{Ma}$ in the North Atlantic Ocean. Rahman and Roth (1989) estimate this event at $1.68 \mathrm{Ma}$ in the Gulf of Aden.

Nannofossil zones recognized in the middle and lower Miocene are the Discoaster exilis Zone, the Sphenolithus heteromorphus Zone, and the Helicosphaera ampliaperta Zone. The $D$. exilis Zone is divided into the Discoaster kugleri and Coccolithus miopelagicus Subzones. Bukry (1973) used the FO of D. kugleri and the LO of Cyclicargolithus floridanus to define the base of the D. kugleri Subzone and the top of the C. miopelagicus Subzone. In the Japan Sea, D. kugleri and C. floridanus occur together for part of the middle Miocene at Sites 794 and 797. This suggests that (1) the FO of D. kugleri, or the LO of C. floridanus is diachronous, (2) that both are diachronous, or (3) that specimens of $C$. floridanus are reworked. The LO of $C$. floridanus was used in this study to differentiate the $D$. kugleri and $C$. miopelagicus Subzones, because this species is more abundant and more easily identified than $D$. kugleri. The latter species occurs sporadically and is difficult to recognize because of overgrowth.

The LO of Sphenolithus heteromorphus is dated at $14 \mathrm{Ma}$ in the Pacific Ocean by calibrating nannofossil events with magnetostratigraphy (Barron et al., 1985a). Backman et al. (1990) used similar methods to derive an estimate at $13.6 \mathrm{Ma}$ for the Indian Ocean. The former estimate is accepted in this study because the latter authors indicated a low rate of sedimentation close to the LO of $S$. heteromorphus, as also indicated by their placement of the LO of Cyclicargolithus floridanus either coeval or closely following the LO of $S$. heteromorphus.

The age of the FO of Sphenolithus heteromorphus is estimated at 17.5 Ma by Barron et al. (1985b), based on indirect correlation of magnetostratigraphy and planktonic biostratigraphy of Ryan et al. (1974). Berggren et al. (1985) reported an age estimate at $17.1 \mathrm{Ma}$, 
which was based on data from the southwestern Atlantic Ocean (Berggren et al., 1983, p. 685). The original data for this estimate showed sporadic occurrences of $S$. heteromorphus below the accepted level of FO. Thus the FO of $S$. heteromorphus is older than the estimate reported in Berggren et al. (1985). I use an age estimate at 18.4 Ma from the Indian Ocean (Backman et al., 1990), based on correlation of quantitative nannofossil data from closely spaced samples and magnetostratigraphy.

Okada and Bukry (1980) use the acme of Discoaster deflandrei and the FO of Calcidiscus macintyrei to define the base of the Sphenolithus heteromorphus Zone. The latter event is used in this study because the rare and sporadic occurrence of $D$. deflandrei did not allow the recognition of its acme in the Japan Sea. The FO of $C$. macintyrei is dated from the Pacific Ocean at $15.7 \mathrm{Ma}$ by Barron et al. (1985a). This age is close to the age of the acme of $D$. deflandrei recently dated at 16.1 Ma in the Indian Ocean by Rio et al. (1990).

In the following discussion, each of the zonal names is followed by the author name(s), code of Okada and Bukry (1980), definition, and remarks; the discussion is limited to the zones where some remarks are necessary. For the discussion of the rest of the zones and subzones the reader is referred to earlier studies (Hay et al., 1967; Gartner, 1969; Martini, 1971; Bukry, 1973; Okada and Bukry, 1980; Rahman and Roth, 1989).

\section{Umbilicosphaera sibogae Zone Rahman and Roth (1989), CN14a}

\section{Definition}

Interval from the LO of Pseudoemiliania lacunosa to the FO of Gephyrocapsa oceanica.

\section{Remarks}

Both of the datum levels of this zone have been used separately in previous zonal schemes (Hay et al., 1967; Gartner, 1969; Martini, 1971). The Umbilicosphaera sibogae Zone has a shorter duration than the Emiliania ovata Subzone (CN14a) of Okada and Bukry (1980), because of the new age estimate of the FO of G. oceanica.

\section{Gephyrocapsa caribbeanica Zone Bukry (1973), CN13b, Upgraded in this Paper}

\section{Definition}

Interval between the FO's of Gephyrocapsa oceanica and Gephyrocapsa caribbeanica.

\section{Remarks}

The FO events of Gephyrocapsa oceanica and Gephyrocapsa caribbeanica are useful when a broader definition of these two species is used (Rahman and Roth, 1989; Rahman, in press). The $G$. caribbeanica Subzone (CN13b) of Bukry (1973) and Okada and Bukry (1980) is upgraded to a zone in this paper. Due to the new age estimate of the upper marker, the FO of G. oceanica (1.35 Ma; Rahman and Roth, 1989), this zone has a longer duration than CN13b.

\section{SITE SUMMARIES}

Forty-eight species of nannofossils are recognized in 95 samples through light microscopic investigation of 808 samples from 10 holes at four sites of Leg 127. Nannofossils occur in two sedimentary intervals and define four zones in the Holocene to uppermost Pliocene, and three zones (two subzones) in the middle and lower Miocene (Tables 2-5). Nannofossil events recognized in Leg 127 are summarized in Table 6. Taxonomic concepts used in this study are given in Appendix A. The barren samples are listed in Appendix B, so that future nannofossil workers may avoid them.

Delicate taxa are either rare or absent, even in samples with well-preserved nannofossils, suggesting environmental conditions adverse for delicate taxa. Reworked forms are rare which is in agreement with Ellis (1975) from DSDP Site 302 in the Japan Sea. Reticulofenestra pseudoumbilica, which became extinct at $3.56 \mathrm{Ma}$, were reworked into the Pleistocene, and Reticulofenestra umbilica, Discoaster lodoensis, and Nannotetrina, all of Paleogene age, were reworked into the Miocene.

\section{Site 794}

This site is located in the northernmost part of the Yamato Basin at $40^{\circ} 11^{\prime} \mathrm{N}$ and $138^{\circ} 15^{\prime} \mathrm{E}$, at a water depth of $2825 \mathrm{~m}$. Three holes at this site (794A, 794B, 794C) recovered a sedimentary sequence composed of clay and silty clay, clayey diatomaceous ooze, and claystone. These sedimentary rocks are poor in calcium carbonate, except in some thin layers. Hole $794 \mathrm{C}$ encountered a dolerite sill complex at a depth of 534 meters below seafloor (mbsf). ODP Leg 128 drilled two holes (794D, 794E) at this site and recovered a layer of sedimentary rock ( $1.6 \mathrm{~m}$ thick) containing microfossils from a depth of 642.25 mbsf at Hole 794D (Ingle, Suyehiro, von Breymann, et al., 1990).

Nannofossils are present in only 20 out of 163 samples studied in Holes 794A and 794B. Their relative abundance varies from abundant to rare, and the preservation varies from excellent to poor (Table 2). Three nannofossil zones and two subzones are recognized at Site 794, one zone in the Pleistocene, two zones and two subzones in the middle Miocene.

The Emiliania huxleyi Zone is unrecognizable at Site 794. Samples $127-794 \mathrm{~A}-3 \mathrm{H}-2,73-74 \mathrm{~cm}$, through $-4 \mathrm{H}-2,75-76 \mathrm{~cm}$, are assigned to the Umbilicosphaera sibogae Zone of late Pleistocene age, based on the presence of Pseudoemiliania lacunosa and Gephyrocapsa oceanica. The precise position of the zonal boundaries is indeterminate because of barren sedimentary intervals, both above and below.

Gephyrocapsa caribbeanica first occurs with Gephyrocapsa oceanica in Sample 127-794A-4H-2, 75-76 cm, which is underlain by Sample $127-794 \mathrm{~A}-5 \mathrm{H}-3,75-76 \mathrm{~cm}$, containing only two taxa, Coccolithus pelagicus and small Reticulofenestra. This suggests environmental control on the coeval FO's of $G$. caribbeanica and $G$. oceanica. Sample 127-794A-5H-3, 75-76 cm, and 127-794B-1R$\mathrm{CC}$, could not be assigned to any zone because of the lack of marker species. The former sample is probably younger than $3.56 \mathrm{Ma}$ (Berggren et al., 1985; Rahman and Roth, 1989), based on the absence of Reticulofenestra pseudoumbilica. The presence of $R$. pseudoumbilica in the latter sample suggests that it is older than $3.56 \mathrm{Ma}$. Sample 127-794B-1R-CC is followed by a thick barren interval.

Samples 127-794B-7R-1, 3-4 cm, through -7R-CC, are assigned to the Discoaster kugleri Subzone of the Discoaster exilis Zone. The top of this subzone was not recognizable because of the absence of the marker species, Catinaster coalitus. The LO of Cyclicargolithus floridanus located between the Samples 127-794B-7R-CC, and -8RCC, brackets the base of the D. kugleri Subzone. Samples 127-794B$8 \mathrm{R}-\mathrm{CC}$, through $-12 \mathrm{R}-1,63-64 \mathrm{~cm}$, are assigned to the Coccolithus miopelagicus Subzone of the $D$. exilis Zone, based on the presence of $C$. floridanus and the absence of Sphenolithus heteromorphus. The C. miopelagicus Subzone contains the most diverse nannofossil assemblage at Site 794.

Samples from $127-794 \mathrm{~B}-12 \mathrm{R}-1,86-87 \mathrm{~cm}$, to $-13 \mathrm{R}-\mathrm{CC}$ are assigned to the Sphenolithus heteromorphus Zone, based on the presence of Calcidiscus macintyrei and $S$. heteromorphus. The FO of $C$. macintyrei at the bottom of the $S$. heteromorphus Zone was unrecognizable at Site 794 because of a barren interval underlying this zone.

Questionable remains of Sphenolithus heteromorphus in Sample 127-794B-25R-1, 17-18 cm, were identified during shipboard study 
Table 2. Stratigraphic distribution, relative abundance, and preservation of calcareous nannofossils at Site 794. Sample interval is in centimeters.

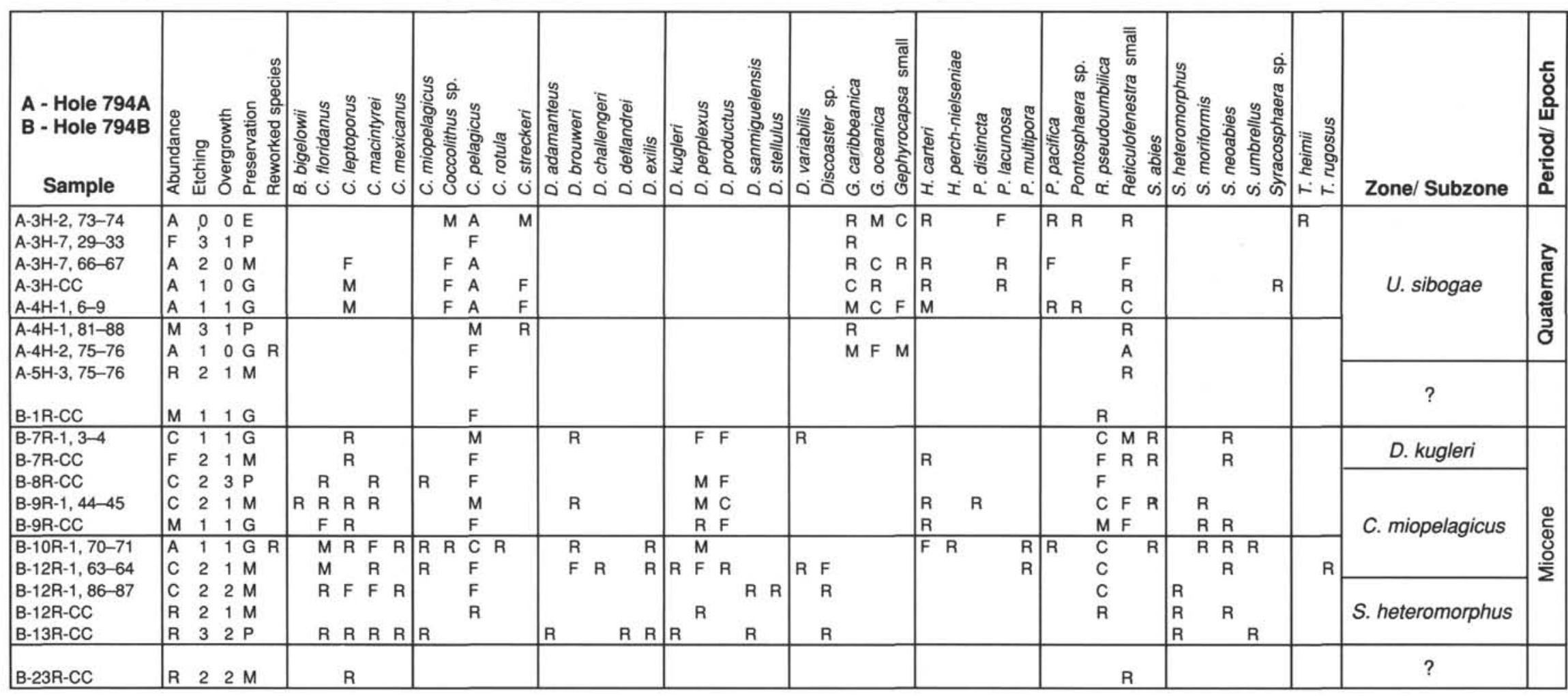

Note: Abbreviations used: for abundance, $\mathrm{A}=$ abundant, $\mathrm{C}=$ common, $\mathrm{M}=$ many, $\mathrm{F}=$ few, $\mathrm{R}=$ rare; for preservation, $\mathrm{E}=$ excellent, $\mathrm{G}=\mathrm{good}, \mathrm{M}=$ moderate, $\mathrm{P}=$ poor; see text for more details. 
Table 3. Stratigraphic distribution, relative abundance, and preservation of calcareous nannofossils at Site 795. See Table 2 for explanation.

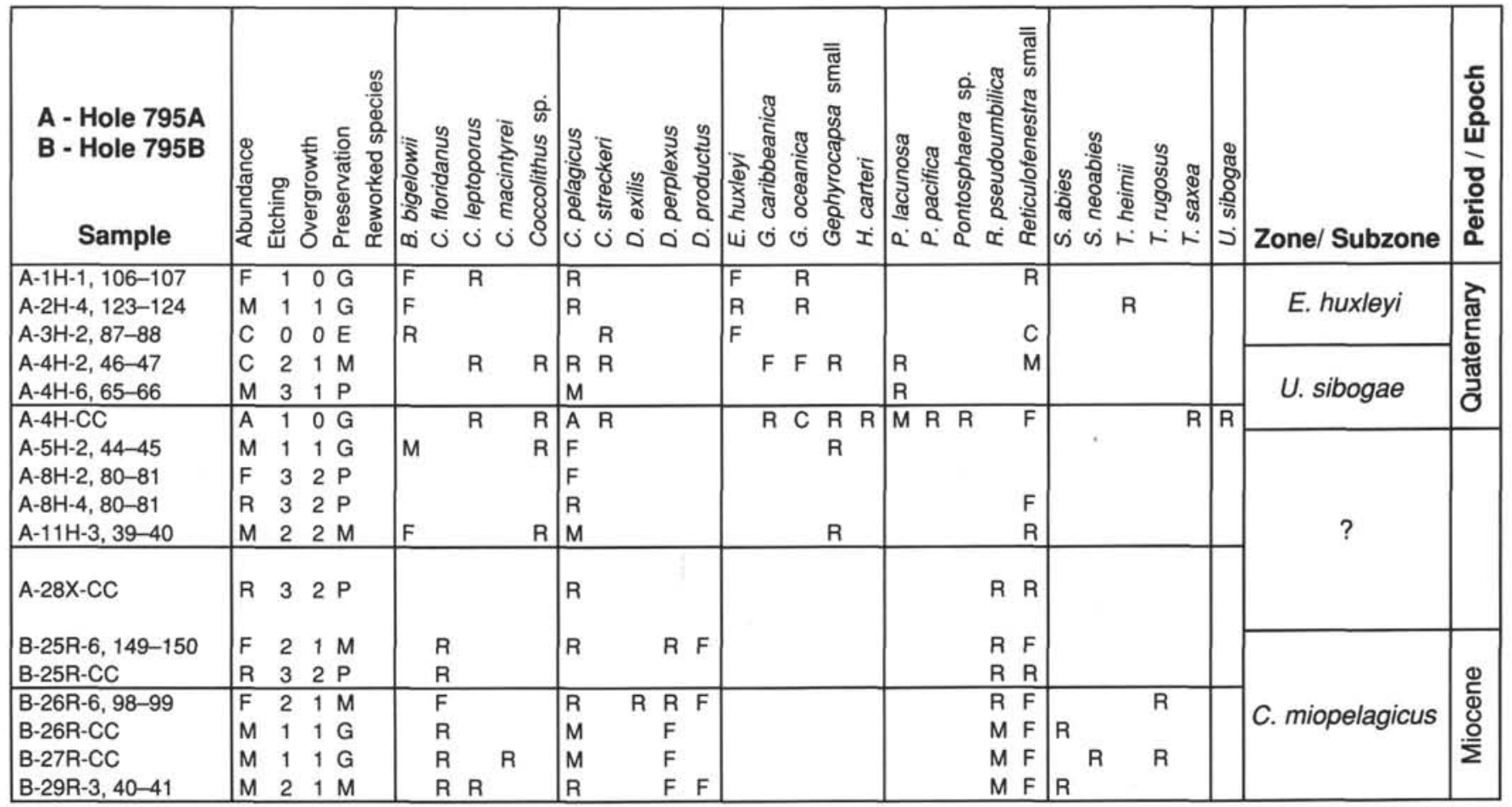

Table 4. Stratigraphic distribution, relative abundance, and preservation of calcareous nannofossils at Site 796. See Table 2 for explanation.

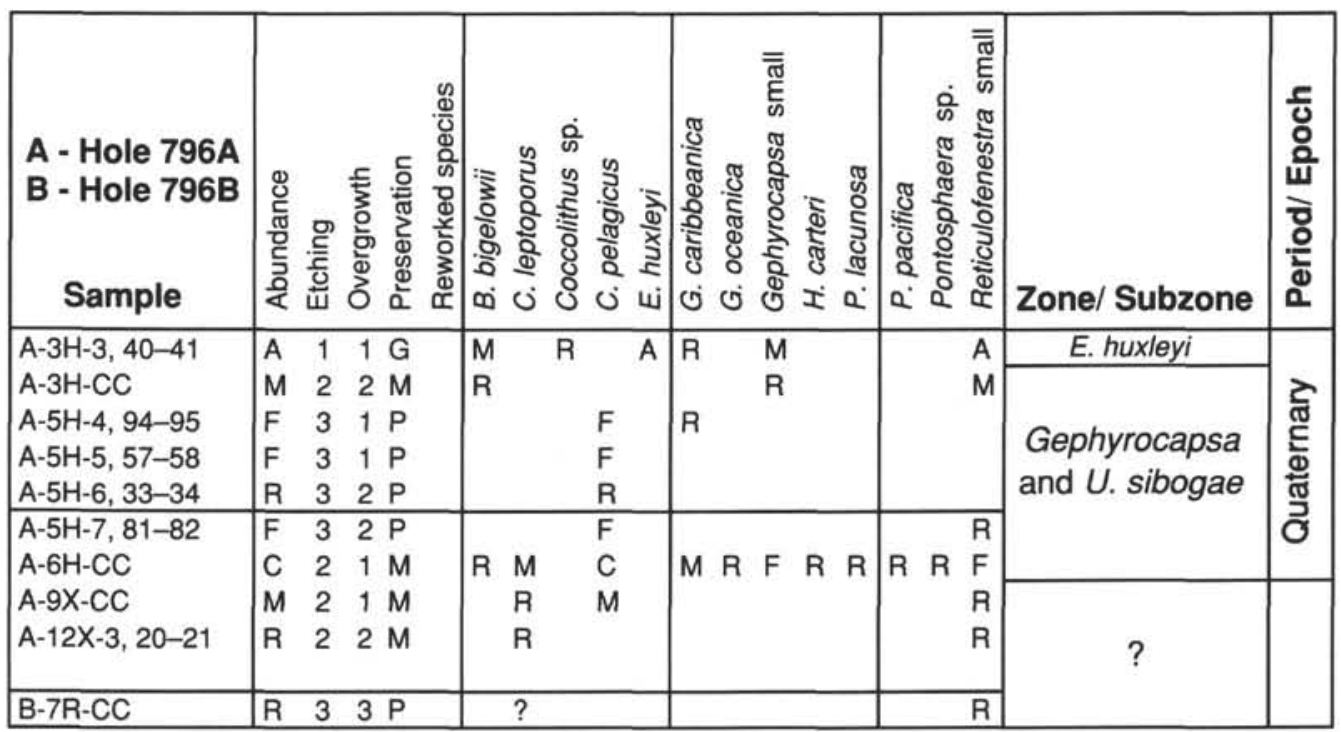

(Tamaki, Pisciotto, Allan, et al., 1990). A long search during the shorebased study, however, did not confirm even a single specimen of this species in Core 127-794B-25R. The lowest sample that contains nannofossils is 127-794B-23R-CC (Table 2). This sample is older than the LO of $S$. heteromorphus, dated at $14 \mathrm{Ma}$ (Barron et al., 1985a).

\section{Site 795}

Site 795 is located at the northern end of the Japan Basin, just off the flank of what appears to be a buried remnant spreading ridge at $44^{\circ} 00^{\prime} \mathrm{N}, 138^{\circ} 52.7^{\prime} \mathrm{E}$, at a water depth of $3374 \mathrm{~m}$. Two holes $(795 \mathrm{~A}$,
795B) drilled at this site recovered a sedimentary sequence similar to that of Site 794, but with a greater proportion of terrigenous sediments. The calcium carbonate content of the sediments is low overall. Hole 795B drilling encountered a basement complex of basaltic rocks at $685 \mathrm{mbsf}$ (Tamaki, Pisciotto, Allan, et al., 1990).

The patterns of nannofossil occurrences at this site are similar to those at the previous site. Nannofossils of Pleistocene, Pliocene, and middle Miocene ages are abundant to rare, well to poorly preserved, and occur sporadically in 17 samples out of 181 samples studied (Table 3). Nannofossil data allowed recognition of two zones in the Holocene to Pliocene and one subzone in the middle Miocene. 
Table 5. Stratigraphic distribution, relative abundance, and preservation of calcareous nannofossils at Site 797. See Table 2 for explanation.

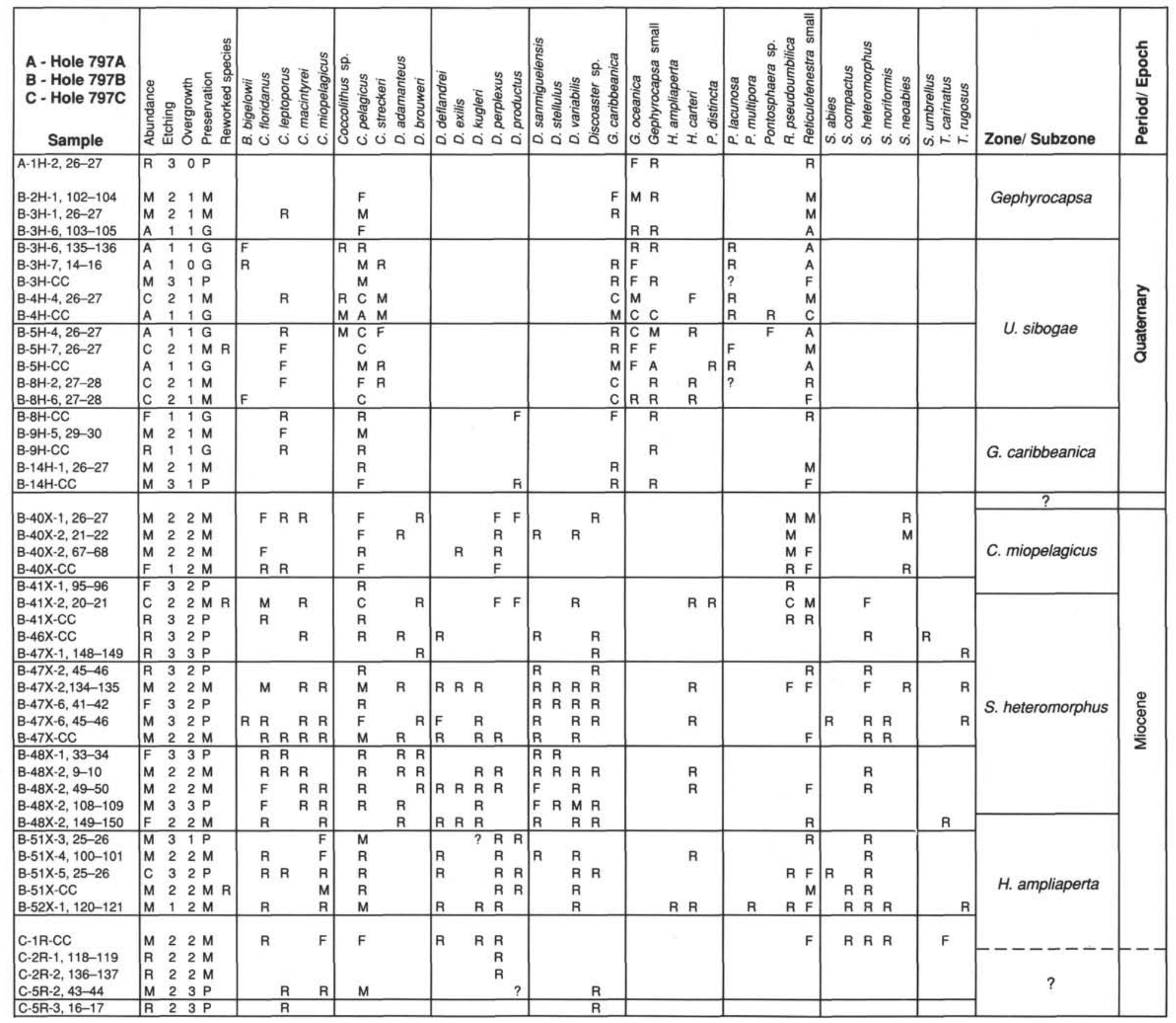


Table 6. Summary of calcareous nannofossil events of Leg 127 (Sites 794-797) in the Japan Sea.

\begin{tabular}{|c|c|c|c|c|c|}
\hline \multirow[b]{2}{*}{ Species } & \multirow[b]{2}{*}{ Event } & \multicolumn{4}{|c|}{ Leg 127} \\
\hline & & Site 794 & Site 795 & Site 796 & Site 797 \\
\hline E. huxleyi & FO & . & A-3H-2, 87-88/ A- $4 \mathrm{H}-2,46-47$ & A- $3 \mathrm{H}-3,40-41 / \mathrm{A}-3 \mathrm{H}-\mathrm{CC}$ & . \\
\hline P. lacunosa & LO & - & A- $-3 \mathrm{H}-2,87-88 / \mathrm{A}-4 \mathrm{H}-2,46-47$ & (2010 & В-3H-6, 103-105/ В-3H-6, 135-136 \\
\hline G. oceanica & FO & - & (2) - & - & B- $8 \mathrm{H}-6,27-28 /$ B- $8 \mathrm{H}-\mathrm{CC}$ \\
\hline C. floridanus & LO & B-7R-CC/ B-8R-CC & . & . & - \\
\hline S. heteromorphus & LO & B-12R-1, 63-64/B-12R-1, 86-87 & - & - & B-41X-1, 95-96/ B-41X-2, 20-21 \\
\hline C. macintyrei & FO & 20. & . & - & B- $48 \mathrm{X}-2,108-109 /$ B- $48 \mathrm{X}-2,149-150$ \\
\hline
\end{tabular}

Note: Sample intervals are in centimeters. A and B with sample numbers designate the holes at a single site, i.e., A at Site 794 represents Hole $794 \mathrm{~A}$. FO = first occurrence, $\mathrm{LO}=$ last occurrence.

Samples from $127-795 \mathrm{~A}-1 \mathrm{H}-1,106-107 \mathrm{~cm}$, through $-3 \mathrm{H}-2,87-8 \mathrm{~cm}$, are assigned to the Emiliania huxleyi Zone, based on the presence of the nominal species. This zone contains few to rare Braarudosphaera bigelowii, a species which is more common in shelf seas than in the open ocean (Perch-Nielsen, 1985). Several whole coccospheres of this species were observed, which suggests the influence of nearshore conditions.

The Gephyrocapsa Zone that directly underlies the Emiliania huxleyi Zone was not recognizable because of a barren interval. Samples 127-795A-4H-2, 46-47 cm, through $-4 \mathrm{H}-\mathrm{CC}$, contain Pseudoemiliania lacunosa and Gephyrocapsa oceanica and thus belong to Umbilicosphaera sibogae Zone. As at Site 794, the precise position of the bottom of this zone is uncertain because $G$. oceanica and Gephyrocapsa caribbeanica first occur in the same sample (Table 3). The coeval FO's of these two species and a low diversity of the assemblage in the underlying sample (127-795A-5H-2, 44-45 $\mathrm{cm}$ ), once again, suggest environmental control on these two events in the lower Pleistocene.

Samples from 127-795A-5H-2, 44-45 cm, to -11H-3, 39-40 cm, belong to the lowermost Pleistocene and the upper Pliocene, based on the absence of Reticulofenestra pseudoumbilica and Gephyrocapsa oceanica. Sample 127-795A-28X-CC, may be anywhere from lower Pliocene to the uppermost middle Miocene, as indicated by the presence of $R$. pseudoumbilica and the absence of Cyclicargolithus floridanus. These samples are not assigned to any zone because of the lack of marker species.

Samples 127-795B-25R-6, 149-150 cm, through -29R-3, 40-41 cm, are assigned to the Coccolithus miopelagicus Subzone of the Discoaster exilis Zone, based on the presence of Cyclicargolithus floridanus and the absence of Sphenolithus heteromorphus. The top of this subzone was unrecognizable because of an overlying barren interval. The lowest nannofossil-bearing sample (127-795B-29R-1, $40-41 \mathrm{~cm}$ ) occurs between the LO's of $C$. floridanus $(13.1 \mathrm{Ma}$ ) and S. heteromorphus (14.0 Ma).

\section{Site 796}

Site 796 is located at $42^{\circ} 50^{\prime} \mathrm{N}, 139^{\circ} 25^{\prime} \mathrm{E}$ at a water depth of $2223 \mathrm{~m}$ on the Okushiri Ridge, a complex, thrust-faulted structure along the northeastern flank of the Japan Basin. Two holes (796A, 796B) were drilled through a sedimentary sequence of silty clay, sand, claystone, clayey diatom ooze, diatomite, and siliceous claystone. The sedimentary sequence is poor in calcium carbonate. In contrast to the previous sites, the fine-grained clastic and hemipelagic sediments at this site are interbedded with sandstones, indicating a close proximity to the terrigenous sources.

Nannofossils at Site 796 are less common, less diverse, and more sporadic than at Sites 794 and 795 , occurring only in 10 out of 164 samples studied (Table 4). They are abundant to rare, and well- to poorly preserved. Three nannofossil zones are defined in the Holocene to the upper Pliocene.

Sample 127-796A-3H-3, 40-41 cm, belongs to the Emiliania huxleyi Zone, based on the presence of the nominal species. This sample contains abundant well-preserved nannofossils, including coccospheres of Braarudosphaera bigelowii, indicating the influence of a nearshore environment.

The samples from 127-796A-3H-CC, to -6H-CC, probably belong to the undifferentiated Gephyrocapsa and Umbilicosphaera sibogae Zones of Pleistocene age, based on the absence of Emiliania huxleyi, and the presence of Gephyrocapsa oceanica in the latter sample. Pseudoemliania lacunosa is present only in one sample (127-796A$6 \mathrm{H}-\mathrm{CC})$, which precluded the separation of these two zones. The position of the base of this combined Gephyrocapsa-U. sibogae Zone was unrecognizable because G. oceanica and Gephyrocapsa caribbeanica first occur in the same sample, as at Sites 794 and 795.

Samples between 127-796A-9X-CC, and -796B-7R-CC, belong to the lowermost Pleistocene and upper Pliocene, based on the absence of Gephyrocapsa oceanica, Sphenolithus, and Reticulofenestra pseudoumbilica. These samples are not assigned to any zone because of lack of marker species.

The lowest sample containing nannofossils (127-796B-7R-CC) belongs to the uppermost Pliocene, based on diatom biostratigraphy (Tamaki, Pisciotto, Allan, et al., 1990). It is unclear whether the lower part of Hole 796B reached the middle Miocene. This issue remained unresolved in the shipboard study. The only age control available in the lower part of the sedimentary sequence of Hole 796B was the occurrence of planktonic foraminifer Globigerina bulloides in Samples 127-796B32R-4, 143-145 cm, and -32R-5, 24-25 cm (Tamaki, Pisciotto, Allan, et al., 1990). The FO of this species is dated at $16 \mathrm{Ma}$ (Berggren et al., 1985), which brackets the maximum age of the samples.

All the other sites of Leg 127 except Site 796 contain nannofossils in middle Miocene sedimentary rocks; some of the samples are even younger than the LO of Sphenolithus heteromorphus (14 Ma). At Site 794, nannofossils occur above the LO of Cyclicargolithus floridanus (13.1 Ma). These nannofossil occurrences imply that the base of Hole 796B is younger than 13.1 Ma, provided that the temporal distribution of nannofossils in the Japan Sea is controlled only by the surface water conditions, and not by local diagenetic processes.

\section{Site 797}

Site 797 is situated at $38^{\circ} 36.7^{\prime} \mathrm{N}, 134^{\circ} 32.6^{\prime} \mathrm{E}$ at a water depth of $2945 \mathrm{~m}$ in the southern part of the Yamato Basin and east of the Yamato Rise. Three holes (797A, 797B, 797C) were drilled and recovered a thick sedimentary sequence of silty clay, diatomaceous clay, clayey diatomaceous ooze, claystone, and tuff in the upper part, with interbedded sandstone, siltstone, and silty claystone in the lower part. Hole 797C encountered a basement complex of basalts and dolerites interlayered with coarse- to fine-grained clastic sedimentary rocks.

Compared to the Sites 794 and 796 , Site 797 is situated at a greater water depth. This site has the highest content of calcium carbonate in the sediments, the most complete nannofossil record, and the most diverse nannofossil assemblages. All these observations can be attributed to warmer surface water. Nannofossils are abundant to rare, and 
well to poorly preserved in 48 of 300 samples studied (Table 5). Six zones are recognized at Site 797, three zones in the Pleistocene, three zones and one subzone in the middle to lower Miocene.

Samples 127-797A-1H-2, 26-27 cm, through -797B-3H-6, $103-$ $105 \mathrm{~cm}$, are assigned to the Gephyrocapsa Zone, based on the absence of Emiliania huxleyi and Pseudoemiliania lacunosa. The latter species last occurs between Samples 127-797B-3H-6, 103-105 cm, and $-135-136 \mathrm{~cm}$ (Table 5).

The Samples 127-797B-3H-6, 135-136 cm, through -8H-6, 27-28 $\mathrm{cm}$, belong to the Umbilicosphaera sibogae Zone, based on the presence of Gephyrocapsa oceanica and Pseudoemiliania lacunosa. This zone also contains rare to abundant small reticulofenestrids, small Gephyrocapsa, Coccolithus pelagicus, and rare to common Gephyrocapsa caribbeanica. The FO of G. oceanica that marks the bottom of the $U$. sibogae Zone occurs between Samples 127-797B$8 \mathrm{H}-6,27-28 \mathrm{~cm}$, and $-8 \mathrm{H}-\mathrm{CC}$. Site 797 was the only site of Leg 127 where the $\mathrm{FO}$ of $G$. oceanica was recognized.

Samples 127-797B-8H-CC, through -14H-CC, belong to the Gephyrocapsa caribbeanica Zone of the lower Pleistocene, based on the presence of the nominal species and the absence of Gephyrocapsa oceanica. The bottom marker of this zone, the FO of G. caribbeanica, was not precisely located because of an underlying barren interval. This barren interval was underlain by the Coccolithus miopelagicus Subzone of the Discoaster exilis Zone in the middle Miocene between the Samples 127-797B-40X-1, 26-27 cm, through $-41 X-1,95-96 \mathrm{~cm}$. This subzonal assignment was based on the presence of Cyclicargolithus floridanus and the absence of Sphenolithus heteromorphus. In contrast to Site 794, the precise depth of the LO of Cyclicargolithus floridanus is unknown at Site 797, which perhaps can be attributed to the lack of recovery of the Cores 127-797B-38R to $-40 \mathrm{R}$. The depth of this event is, however, constrained by the base of the diatom zone Rouxia californica (7.20 Ma) in Sample 127-797B-37X-CC (Tamaki, Pisciotto, Allan, et al., 1990). This sample and the apparent LO of $C$. floridanus identified an interval of reduced sedimentation rate that may include a hiatus.

Samples 127-797B-41X-2, 20-21 cm, through -48X-2, 108-109 cm, belong to the Sphenolithus heteromorphus Zone, based on the presence of $S$. heteromorphus and Calcidiscus macintyrei. Nannofossil assemblages within the lower part of this zone are the most diverse of Site 797 and other sites of Leg 127. Discoasters are more frequent throughout this interval.

Based on the presence of Sphenolithus heteromorphus and the absence of Calcidiscus macintyrei, the samples between 127-797B$48 \mathrm{X}-2,149-150 \mathrm{~cm}$, and $-797 \mathrm{C}-1 \mathrm{R}-\mathrm{CC}$, are assigned to the Helicosphaera ampliaperta Zone. The lowest occurrence of $S$. heteromorphus is in Sample 127-797C-1R-CC. It is unclear whether the occurrence of $S$. heteromorphus in this sample represents the FO of this species. Below Sample 127-797C-1R-CC, nannofossils are present, but only in four samples. Nannofossil assemblages in these samples consist of a few taxa such as Calcidiscus leptoporus, Coccolithus pelagicus, Dictyococcites perplexus, Coccolithus miopelagicus, and discoasters, which are unidentifiable to the species level because of strong overgrowth.

Sample 127-797C-5R-3, 16-17 cm, is the oldest nannofossil-bearing sample at Site 797. The minimum age of this sample is constrained by the FO of Calcidiscus macintyrei (15.7 Ma) in Sample 127-797B$48 \mathrm{X}-2,108-109 \mathrm{~cm}$. Its age may be anywhere between 15.7 and 18.4 $\mathrm{Ma}$, and may even be older if the FO of Sphenolithus heteromorphus at Site 797 is not affected by diagenesis or by the presence of adverse surface-water conditions in the early Miocene.

\section{DISCUSSION}

\section{Importance of Nannofossil Biostratigraphic Results}

The sedimentary sequence of Leg 127 has the most diverse and complete nannofossil record ever recovered from the Japan Sea. Despite their spotty distribution, nannofossils provided age controls in the middle and lower Miocene. Other microfossil groups such as foraminifers, radiolarians, and diatoms do not provide more precise age information than nannofossils in this interval. Furthermore, the problems of remagnetization, erratic magnetic directions, low intensity of remanent magnetization, and poor core recovery precluded the use of magnetostratigraphy in the Miocene sedimentary rocks (Tamaki, Pisciotto, Allan, et al., 1990). The nannofossil biostratigraphic results of this study put constraints on the minimum age of the Japan Sea, and allow a check of one of the most cited models explaining the opening of the Japan Sea (Otofuji et al., 1985a, 1985b).

The model of Otofuji et al. (1985a) suggests a rapid clockwise rotation $\left(\sim 50^{\circ}\right)$ of southwest Japan in the middle Miocene at about $15 \mathrm{Ma}$, based on change in the direction of paleomagnetic declinations recorded in the Japanese islands. A similar study in the northern part of Japan proposed a counter-clockwise rotation of northeast Japan between 12 and $21 \mathrm{Ma}$ (Otofuji et al., 1985b). These rotations occurred simultaneously as the result of the oceanward migration of the Japanese islands that gave rise to the fan-like opening of the Japan Sea backarc basin (Otofuji et al., 1985b; Kimura and Tamaki, 1986; Otofuji and Matsuda,1987; Tatsumi et al., 1989; Honkura et al., 1991). This model suggests that the Japanese islands were parallel to the Eurasian margin and that the Yamato Basin did not open before the bending of the Japanese islands. According to Otofuji et al. (1985a), the rotational motion for southwest Japan lasted for a short time interval of less than $1 \mathrm{~m} . y$., thus requiring an extremely high rate of seafloor spreading that is not supported by the presently known spreading rates (Celaya and McCabe, 1987).

Nannofossil records at Site 797 show the existence of the southern Yamato Basin already in the early middle Miocene, earlier than the FO of Calcidiscus macintyrei (15.7 Ma). This is consistent with data from Site 794 in the northern Yamato Basin, where the earliest nannofossil record in Hole $794 \mathrm{C}$ is older than the LO of Sphenolithus heteromorphus (14 Ma). The actual age of the basin at this site is perhaps much older than $14 \mathrm{Ma}$, because marine diatoms, radiolarians, and foraminifers occur within a sedimentary layer at the base of Hole 794D, and the benthic foraminifers indicate a deep-water environment (Ingle, Suyehiro, von Breymann, et al., 1990). The age of Japan Basin at Site 795 is older than the LO of Cyclicargolithus floridanus (13.1 Ma). This study shows that at least the Yamato Basin was formed before the rotation of southwest Japan, and also that the latter event cannot be directly attributed to the initial opening of the Japan Sea as previously claimed by some workers. The new results warrant a consideration of other event(s) or mechanism(s) (e.g., Lallemand and Jolivet, 1986). Any kinematic model proposed in the future should be able to explain the age constraints based on nannofossil biostratigraphy of Leg 127.

\section{Nannofossil Assemblage and Paleoceanographic Inferences}

The nannofossil assemblages in the Holocene to Pliocene sedimentary rocks of the Japan Sea are dominated by Gephyrocapsa caribbeanica, Gephyrocapsa oceanica, Coccolithus pelagicus, small reticulofenestrids, and small Gephyrocapsa. The assemblages are diverse in the lower middle Miocene to upper lower Miocene and contain mainly C. pelagicus, Reticulofenestra pseudoumbilica, Cyclicargolithus floridanus, and small reticulofenestrids, with relatively rare Sphenolithus heteromorphus, Sphenolithus moriformis, Sphenolithus abies, Sphenolithus neoabies, Helicosphaera carteri, Calcidiscus macintyrei, and discoasters.

Figure 3 shows a summary of nannofossil diversity in the sedimentary sequence of Leg 127 . This figure is a plot of the number of nannofossils species against zones/ subzones and age. The diversity varied from 20 to 27 taxa within the interval between Helicosphaera ampliaperta Zone (CN3) and Coccolithus miopelagicus Subzone (CN5a). Diversity dropped sharply within the Discoaster kugleri Subzone (CN5b), and varied from 6 to 14 taxa between Pseu- 

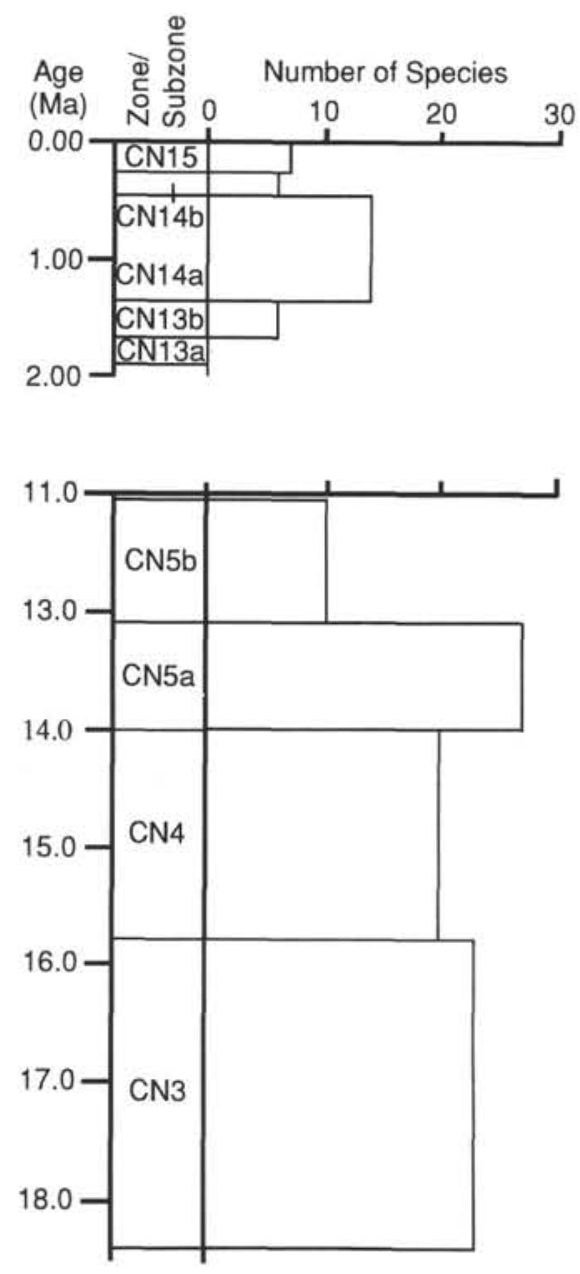

Figure 3. Calcareous nannofossil diversity in the sedimentary sequence recovered during Leg 127. Number of taxa, from all sites, are plotted against zones and subzones (Okada and Bukry, 1980; this paper) and age.

\section{doemiliania lacunosa Subzone (CN13a) and Emiliania huxleyi Zone (CN15).}

The surface-water temperature in the northern part of the Japan Sea is low and that part of the sea shows large seasonal fluctuations of temperature and salinity (Hidaka, 1966). Within the southeastern Japan Sea, surface water is warmer, a condition that is directly related to the flow of the warm Tsushima Current (Hidaka, 1966). This influx of warm water from the south is closely tied to the eustatic sea level, because of the shallow depth of the Tsushima Strait. Low sea level reduced or stopped the influx of warm water from the Pacific Ocean and substantially lowered the surface water temperature. This relation has been shown in several studies based on microfossils in piston cores that recovered the Quaternary sequence from the Japan Sea (Ujiié, 1982; Maiya et al., 1976; Koizumi, 1987).

The present environmental conditions of the Japan Sea are not conducive for tropical nannofossil taxa such as Sphenolithus and discoasters (Haq and Malmgren, 1982; Wei and Wise, 1989), that require warm temperature and small seasonal fluctuation of temperature. Thus, the presence of these taxa in the lower middle Miocene to upper lower Miocene sediments of the Yamato Basin suggests a warm and stable surface-water condition, which agrees with the paleontologic record along the Japan Sea coasts of southwest and central Japan and the Korean Peninsula. Planktonic foraminifers, larger foraminifers, and mollusks suggest a tropical to subtropical climate from the latest early Miocene to the early middle Miocene (Saito, 1963; Itoigawa, 1978; Tsuchi , 1981, 1990; Matoba, 1984; Chinzei, 1986). This warm fauna was distributed along the Japan Sea coasts as far north as $44^{\circ} \mathrm{N}$ latitude off the Japanese Islands and $41^{\circ} \mathrm{N}$ off the Korean Peninsula, indicating a more equable environmental condition than at present.

The warm as surface-water conditions of the Japan Sea from the late early Miocene to early middle Miocene suggest a greater influx of warm surface water from the tropical western Pacific Ocean. This is supported by Matoba (1984), whose conclusions, based on foraminifers, proposed a deep-water connection between the southern part of the Japan Sea and the Pacific Ocean during the middle Miocene, and is also consistent with Chough and Barg (1987), who showed that the Tsushima Strait was deeper in the middle Miocene and became shallower in the latest middle Miocene to earliest late Miocene. Beside a deeper Tsushima Strait, warm water from the Pacific Ocean probably entered the Japan Sea through epicontinental seaways (Tsuchi, 1981; Chinzei, 1986; lijima et al., 1988), and was aided by a high eustatic sea level during the early middle Miocene (Haq et al., 1987). Iijima et al. (1988) suggested the existence of a basin of upper to middle bathyal depth from Niigata to northeastern Noto Peninsula, probably connecting the Japan Sea with the Pacific Ocean.

The environment of the Japan Sea changed in the late middle Miocene (Matoba, 1984). During the rotation of the southwest and northeast Japan (Otofuji et al., 1985a, 1985b) when the sea level was relatively low (Haq et al., 1987), the seaway to the south was closed, thus preventing the inflow of warm currents; the opening the Japan Sea to the north increased the influence of cold water (Matoba, 1984; Chinzei, 1986). The presence of a barren interval close to the LO of Cyclicargolithus floridanus (13.1 Ma) precludes the confirmation of the change in surface-water condition in the late middle Miocene based on nannofossils. The surface-water cooling, however, did not occur before 13.1 Ma, as indicated by the presence of Sphenolithus abies and Sphenolithus neoabies in two samples (127-794B-7R-1, $3-4 \mathrm{~cm}$, and $-7 \mathrm{R}-\mathrm{CC}$ ) above the LO of C. floridanus at Site 794. This age constraint for the change in water condition is supported by faunal and floral changes in the Japanese land sections (Saito, 1963; Takayangi et al., 1976). These authors reported a change from warm water biofacies to cool temperate and subarctic biofacies immediately above the Globorotalia fohsi fohsi Zone, a planktonic foraminifer zone, the top of which is dated at $13.1 \mathrm{Ma}$ (Berggren et al., 1985). The surface -water cooling in the Japan Sea was coeval to a global change in climate that is reflected in extensive growth of east Antarctic icesheets (Barker et al., 1988).

Sporadic occurrence of low-diversity nannofossil assemblages in the Holocene to uppermost Pliocene is consistent with strong environmental fluctuations that are based on variation of diatom and radiolarian assemblages, and alteration of dark and white color bands in the sediments (Tamaki, Pisciotto, Allan, et al., 1990; Ingle, Suyehiro, von Breymann, et al., 1990; Tada et al., this volume). Sedimentary intervals containing nannofossils were probably deposited during warm surface-water conditions, when eustatic sea level was high. In the Pleistocene sediments of the northern part of the Japan Sea, the presence of Gephyrocapsa oceanica (Ellis, 1975; this study), which is presently living within a temperature range of $18^{\circ}-29^{\circ} \mathrm{C}$ (McIntyre et al., 1970; Honjo, 1977), suggests a warmer surface -water temperature than at present. Within the present oceanographic setting, a warming in the northern part of the Japan Sea could be obtained by a strong influx of warm water from the Tsushima Current.

\section{CONCLUSION}

1. Nannofossils occur sporadically at all sites of Leg 127 in the Japan Sea and allow recognition of seven zones and two subzones in 
two sedimentary intervals, the upper one in the Holocene to uppermost Pliocene, and the lower one in upper lower Miocene to lower middle Miocene.

2. Assemblages are less diverse in the upper sedimentary interval, and more diverse with warm water nannofossil taxa in the lower sedimentary interval, indicating a warm and stable surface-water condition related to a greater influx of warm water into the Japan Sea from the Pacific Ocean.

3. Nannofossil assemblages are most diverse and best recorded at Site 797 in the Yamato Basin. This site also has the oldest nannofossil record of all sites, older than the FO of Calcidiscus macintyrei (15.7 Ma).

4. This study suggests that the Yamato Basin existed before the rotation of southwest Japan, and that the rotation was not related to the initial opening phase of the Japan Sea.

\section{ACKNOWLEDGMENTS}

Peter H. Roth, Francis H. Brown, Mark V. Filewich, Wuchang Wei, John A. Barron, John Welsh, and Hiromi Honda reviewed this paper. Their comments and criticisms are appreciated. Fahima Rahman and Marge Gundry assisted with sample preparation. Samples were supplied by the U.S. National Science Foundation through the assistance of the Ocean Drilling Program, Texas A \& M University. This study was partly funded by U.S. Science Advisory Committee.

\section{REFERENCES}

Backman, J., 1980. Miocene-Pliocene nannofossils and sedimentation rates in the Hatton-Rockall Basin, NE Atlantic Ocean. Stockholm Contrib. Geol., 36:1-91.

Backman, J., Schneider, D. A., Rio, D., and Okada, H., 1990. Neogene low-latitude magnetostratigraphy from Site 710 and revised age estimates of Miocene nannofossil events. In Duncan, R. A., Backman, J., Peterson, L. C., et al., Proc. ODP, Sci. Results, 115: College Station, TX (Ocean Drilling Program), 271-276.

Backman, J., and Shackleton, N. J., 1983. Quantitative biochronology of Pliocene and early Pleistocene calcareous nannofossils from the Atlantic, Indian and Pacific oceans. Mar. Micropaleontol., 8:141-170.

Barker, P. F., Kennett, J. P., and Leg 113 Shipboard Scientific Party, 1988. Weddell Sea palaeoceanography: preliminary results of ODP Leg 113. Palaeogeogr., Palaeoclimatol., Palaeocol., 67:75-102.

Barron, J. A., Keller, G., and Dunn, D. A., 1985a. A multiple microfossil biochronology for the Miocene. In Kennett, J. P. (Ed.), The Miocene Ocean: Paleoceanography and Biogeography. Mem.-Geol. Soc. Am., 163:21-36

Barron, J. A., Nigrini, C. A., Pujos, A., Saito, T., Theyer, F., Thomus, E., and Weinreich, N., 1985b. Synthesis of biostratigraphy, central equatorial Pacific, Deep Sea Drilling Project Leg 85: refinement of Oligocene to Quaternary biochronology. In Mayer, L., Theyer, F., Thomas, E., et al., Init. Repts. DSDP, 85: Washington (U.S. Govt. Printing Office), 905-934.

Berggren, W. A., Aubry, M. P., and Hamilton, N., 1983. Neogene magnetobiostratigraphy of Deep Sea Drilling Project Site 516 (Rio Grande Rise, South Atlantic). In Barker, P. F., Carlson, R. L., and Johnson, D. A. (Eds.), Init. Repts. DSDP, 72: Washington (U.S. Govt. Printing Office), 675-713.

Berggren, W. A., Kent, D. V., and Van Couvering, J. A., 1985. The Neogene: Part 2. Neogene geochronology and chronostratigraphy. In Snelling, N. J. (Ed.), The Chronology of the Geological Record. Mem.-Geol. Soc. Am., 10:211-260.

Bukry, D., 1971. Discoaster evolutionary trends. Micropaleontology, 17:43-52. 1973. Low-latitude coccolith biostratigraphic zonation. In Edgar. N. T., Saunders, J. B., et al., Init. Repts. DSDP, 15: Washington (U.S. Govt. Printing Office), 685-703.

, 1978. Biostratigraphy of Cenozoic marine sediment by calcareous nannofossils. Micropaleontology, 24:44-60.

Burns, D. A., 1975. Distribution, abundance, and preservation of nannofossils in Eocene to Recent Antarctic sediments. N.Z. J. Geol. Geophys., 18:583-595.

Celaya, M., and McCabe, R., 1987. Kinematic model for the opening of the Sea of Japan and the bending of the Japanese islands. Geology, 15:53-57.

Chinzei, K., 1986. Faunal succession and geographic distribution of Neogene molluscan faunas in Japan. Paleontol. Soc. Jpn., 29:17-32.

Chough, S. K., and Barg, E., 1987. Tectonic history of Illeung basin margin, East Sea (Sea of Japan). Geology, 15:45-48.
Ellis, C. H., 1975. Calcareous nannofossil biostratigraphy-Leg 31, DSDP. In Karig, D. E., Ingle, J. C., Jr., et al., Init. Repts. DSDP, 31: Washington (U.S. Govt. Printing Office), 655-676.

Gartner, S., 1969. Correlation of Neogene planktonic foraminifer and calcareous nannofossils zones. Trans. Gulf Coast Assoc. Geol. Soc., 19:585-599.

, 1977. Calcareous nannofossil biostratigraphy and revised zonation of the Pleistocene. Mar. Micropaleontol., 2:1-25.

Haq, B. U., Hardenbol, J., and Vail, P. R., 1987. Chronology of fluctuating sea levels since the Triassic. Science, 235:1156-1167.

Haq, B. U., and Malmgren, B. A., 1982. Potential of calcareous nannoplankton in paleoenvironmental interpretations-a case study of the Miocene of the Atlantic Ocean. Stockholm Contrib. Geol., 37:79-98.

Hay, W. W., Mohler, H., Roth, P. H., Schmidt, R. R., and Boudreaux, J. E., 1967. Calcareous nannoplankton zonation of the Cenozoic of the Gulf Coast and Caribbean-Antillean area, and transoceanic correlation. Trans. Gulf Coast Assoc. Geol. Soc., 17:428-480.

Hidaka, K., 1966. Japan Sea. In Fairbridge, R. W. (Ed.), The Encyclopedia of Oceanography. Encyclopedia of Earth Sci. Ser. (Vol. 1): New York (Reinhold), 417-424.

Honjo, S., 1977. Biogeography and provincialism of living coccolithophorids in the Pacific Ocean. In Ramsey, A.T.S. (Ed.), Oceanic Micropaleontology: San Diego (Academic), 951-972.

Honkura, Y., Okubo, Y., Nagaya, K., Makino, M., and Oshima, S., 1991. A magnetic anomaly map in the Japanese Region with special reference to tectonic implications. J. Geomagn. Geoelectr., 43:71-76.

Iijima, A., Tada, R., and Watanabe, Y., 1988. Developments of Neogene sedimentary basins in the northeastern Honshu Arc with emphasis on Miocene siliceous deposits. J. Fac. Sci., Univ. Tokyo, 21:417-446.

Ingle, J. C., Jr., Suyehiro, K., von Breymann, M. T., et al., 1990. Proc. ODP, Init. Repts., 128: College Station, TX (Ocean Drilling Program).

Itoigawa, J., 1978. Evidence of subtropical environments in the Miocene of Japan. Bull. Mizunami Fossil Mus., 5:7-21.

Karig, D. E., Ingle, J. C., Jr., et al., 1975. Init. Repts. DSDP, 31: Washington (U.S. Govt. Printing Office).

Kimura, G., and Tamaki, K., 1986. Collision, rotation, and back-arc spreading in the region of the Okhotsk and Japan seas. Tectonics, 5:389-401.

Knüttel, S., 1986. Calcareous nannofossil biostratigraphy of the East Pacific Rise, Deep Sea Drilling Project Leg 92: evidence for downslope transport of sediments. In Leinen, M., Rea, D. K., et al., Init. Repts. DSDP, 92: Washington (U.S. Govt. Printing Office), 225-290.

Kobayashi, K., 1985. Sea of Japan and Okinawa Trough. In Nairn, A.E.M., Stehli, F. G., and Uyeda, S. (Eds.), The Ocean Basins and Margins (Vol. 7A): The Pacific Ocean: New York (Plenum), 419-450.

Koizumi, I., 1987. Pulses of Tsushima Current during the Holocene. Quat. Res. Tokyo, 26:13-25. (in Japanese with English abstract)

Lallemand, S., and Jolivet, L., 1986. Japan Sea: a pull-apart basin? Earth Planet. Sci. Lett., 76:375-389.

Leg 127 Shipboard Scientific Party, 1989. Exploring the Japan Sea. Geotimes, 34:19-21.

Maiya, S., Saito, T., and Sato, T., 1976. Late Cenozoic planktonic biostratigraphy of northwest Pacific sedimentary sequences. In Takayanagi, Y., and Saito, T. (Eds.), Progress in Micropaleontology: New York (Micropaleontology Press), 395-422.

Martini, E., 1971. Standard Tertiary calcareous nannoplankton zonation. In Farinacci, A. (Ed.), Proc. 2nd Planktonic Conf. Roma, Rome (Ed. Tecnosci.), 2:739-785.

Matoba, Y., 1984. Paleoenvironment of the Sea of Japan. In Oertli, H. J. (Ed.), Benthos '83, 2nd Int. Symp. Benthic Foraminifera, 409-414.

McIntyre, A., Bé, W. H., and Roche, M. B., 1970. Modern Pacific Coccolithophorida: a paleontological thermometer. Trans. N.Y. Acad. Sci., 32:720-731.

Okada, H., and Bukry, D., 1980. Supplementary modification and introduction of code numbers to the low-latitude coccolith biostratigraphic zonation (Bukry, 1973; 1975). Mar. Micropaleontol., 5:321-325.

Otofuji, Y., Hayashida, A., and Torii, M., 1985. When was the Japan Sea opened? Paleomagnetic evidence from Southwest Japan. In Nasu, N., Uyeda, S., Kushiro, I., Kobayashi, K., and Kagami, H. (Eds.), Formations of Active Ocean Margins: Tokyo (Terra Publ.), 551-566.

Otofuji, Y., and Matsuda, T., 1987. Amount of clockwise rotation of Southwest Japan-fan shape opening of the southwestern part of the Japan Sea. Earth Planet. Sci. Lett., 85:289-301.

Otofuji, Y., Matsuda, T., and Nohda, S., 1985. Paleomagnetic evidence for the Miocene counter-clockwise rotation of Northeast Japan-rifting process of the Japan Arc. Earth Planet. Sci. Lett., 75:265-277. 
Perch-Nielsen, K., 1985. Cenozoic calcareous nannofossils. In Bolli, H. M. Saunders, J. B., and Perch-Nielsen, K. (Eds.), Plankton Stratigraphy: Cambridge (Cambridge Univ. Press), 427-554.

Rahman, A., in press. Late Neogene calcareous nannofossil biostratigraphy of the Blake Outer Ridge, DSDP Site 533, northwestern Atlantic Ocean. N. Jb. Geol. Paläont.

Rahman, A., and Roth, P. H., 1989. Late Neogene calcareous nannofossil biostratigraphy of the Gulf of Aden region. Mar. Micropaleontol., 15:1-27.

Rio, D., Fornaciari, E., and Raffi, I., 1990. Late Oligocene through early Pleistocene calcareous nannofossils from western equatorial Indian Ocean (ODP Leg 115). In Duncan, R. A., Backman, J., Peterson, L. C., et al., Proc. ODP, Sci. Results, 115: College Station, TX (Ocean Drilling Program), 175-235.

Roche, M. B., McIntyre, A., and Imbrie, J., 1975. Quantitative paleoceanography of the Late Pleistocene-Holocene North Atlantic: coccolith evidence. In Saito, T., and Burckle, L. H. (Eds.), Late Neogene Epoch Boundaries: New York (Micropaleontology Press), 199-225.

Roth, P. H., 1974. Calcareous nannofossils from the northwestern Indian Ocean, Leg 24, Deep Sea Drilling Project. In Fisher, R. L., Bunce, E. T. et al., Init. Repts. DSDP, 24: Washington (U.S. Govt. Printing Office), 969-994.

Roth, P. H., and Coulbourn, W. T., 1982. Floral and solution patterns of coccoliths in surface sediments of the North Pacific. Mar. Micropaleontol., $7: 1-52$.

Ryan, W.B.F., Cita, M. B., Rawson, M. D., Burckle, L. H., and Saito, T., 1974. A paleomagnetic assignment of Neogene stage boundaries and the development of isochronous datum planes between the Mediterranean, the Pacific and Indian oceans in order to investigate the response of the world ocean to the Mediterranean "Salinity Crisis." Riv. Ital. Paleontol., 80:631-688.

Saito, T., 1963. Miocene planktonic foraminifera from Honshu, Japan. Sci. Rep. Tohoko Univ., Ser. 2, 35:123-218.

Takayama, T., and Sato, T., 1987. Coccolith biostratigraphy of the North Atlantic Ocean, Deep Sea Drilling Project Leg 94. In Ruddiman, W. F. Kidd, R. B., et al., Init. Repts. DSDP, 94: Washington (U.S. Govt. Printing Office), 651-702.

Takayanagi, Y., Takayama, T., Sakai, T., Oda, M., and Kitazato, H., 1976. Microbiostratigraphy of some Middle Miocene sequences in northern Japan. In Takayanagi, Y., and Saito, T. (Eds.), Progress in Micropaleontology: New York (Micropaleontology Press), 356-381.

Tamaki, K., 1988. Geological structure of the Japan Sea and its tectonic implications. Chishitsu Chosasho Geppo, 39:269-365.

Tamaki, K., Pisciotto, K., Allan, J., et al., 1990. Proc. ODP, Init. Repts., 127: College Station, TX (Ocean Drilling Program).

Tatsumi, Y., Otofuji, Y., Matsuda, T., and Nohda, S., 1989. Opening of the Japan back-arc basin by asthenospheric injection. Tectonophysics, 166:317-329.

Theodoridis, S., 1984. Calcareous nannofossil biozonation of the Miocene and revision of the helicoliths and discoasters. Utrecht Micropaleontol. Bull., 32.

Thierstein, H. R., Geitzenauer, K. R., Molfino, B., and Shackleton, N. J., 1977. Global synchroneity of late Quaternary coccolith datum levels: validation by oxygen isotopes. Geology, 5:400-404.

Tsuchi, R. (Ed.), 1981. Neogene of Japan-Its Biostratigraphy and Chronology: Shizuoka, Japan (Kurofune Printing).

1990. Neogene events in Japan and the Pacific. Palaeogeogr. Palaeoclimatol., Palaeoecol., 77:355-365.

Ujiié, H., 1982. Geological history of the Sea of Japan: problems from standpoints of sediments and microfossils. In Hoshino, M., and Shibasaki, T. (Eds.), Geology of Japan Sea: Japan (Tokai Univ. Press), 377-428. (in Japanese)

Ujiié, H., and Ichikura, M., 1973. Holocene to uppermost Pleistocene planktonic foraminifers in a piston core from off San'in district, Sea of Japan. Trans. Proc. Palaeontol. Soc. Jpn., 91:137-150.

Wei, W., and Wise, S. W., Jr., 1989. Paleogene calcareous nannofossil magnetobiochronology: results from South Atlantic DSDP Site 516. Mar. Micropaleontol., 14:119-152.

\footnotetext{
Date of initial receipt: 18 March 1991

Date of acceptance: 23 July 1991

Ms 127/128B-123
}

\section{APPENDIX A}

Nannofossil taxa recognized in the present study are arranged below, alphabetically by the genus and species epithets. Each species epithet is followed by the original author(s), by possible subsequent authors who proposed the preferred combinations, and by some remarks if necessary. For taxonomic references of the listed species see Perch-Nielsen (1985) and Rahman and Roth (1989).

Braarudosphaera bigelowii (Gran and Braarud, 1935, p. 389, Fig. 67) Deflandre (1947, p. 439, Figs. 1-5)

Calcidiscus leptoporus (Murray and Blackmann, 1898, p. 430-432, 439)

Loeblich and Tappan (1978, p. 1391).

Remarks: Specimens larger than $8 \mu \mathrm{m}$ in size of this species are observed in the lower Pleistocene. They differ from Calcidiscus macintyrei by having a lower number $(\leq 30)$ of elements.

Calcidiscus macintyrei (Bukry and Bramlette, 1969, p. 132-133, Pl. 1, Figs.

1-3) Loeblich and Tappan (1978, p. 1392).

Remarks: This group includes subelliptical forms of Calcidiscus macintyrei $(=$ Calcidiscus premacintyrei Theodoridis, 1984, p. 81-82, Pl. 2, Figs. 1-3), few specimens of which were observed in the Miocene. In the original description of $C$. macintyrei the number of elements was given as about 40 and the size range of $8-12 \mu \mathrm{m}$. The size cutoff alone cannot differentiate C. macintyrei from Calcidiscus leptoporus because large specimens of the latter species (some exceeding $9.5 \mu \mathrm{m}$ ) were present near the $\mathrm{LO}$ of $C$. macintyrei in the Gulf of Aden area (Rahman and Roth, 1989). Thus, the number of elements has to be considered when distinguishing the large variety of $C$. leptoporus from $C$. macintyrei. The central opening of $C$. macintyrei is larger in the Miocene than in the Pliocene forms.

Catinaster mexicanus Bukry (1971, p. 50, PI. 3, Figs. 7-9).

Coccolithus pelagicus (Wallich, 1877, p. 348, Figs. 1-2, 5, 11-12) Schiller (1930, p. 246, Figs. 123-124).

Remarks: There are variations in the overall coccolith size, and relative size and structure of the central area. The central area may have a small opening, be spanned by a bridge, or be filled.

Coccolithus miopelagicus Bukry (1971, p. 310, Pl. 2, Figs. 6-7). Coccolithus sp.

Remarks: This species has a rim similar to Coccolithus pelagicus and has a granular cross at the center. The bars of the cross are very short and are parallel to the major axes of the coccolith.

Coccolithus streckeri Takayama and Sato (1987, p. 690, Pl. 1, Figs. 4a-4b, Pl. 2, Figs. 1-10, Pl. 8, Fig. 3)

Remark: This species differs from Coccolithus pelagicus by having a large central opening, which is traversed by a delicate bridge paralleling the short axis of the coccolith.

Cyclicargolithus floridanus (Roth and Hay in Hay et al., 1967, p. 445, Pl. 6, Figs. 1-4) Bukry (1971, p. 312-313).

Remark: Cyclicargolithus floridanus varies in outline from circular to broadly elliptical

Cyclolithela rotula (Kamptner, 1956, p. 7) Haq and Berggren (1978, p. 1192. PI. 1, Figs. 15-16).

Dictyococcites perplexus Burns (1975, p. 594, Figs. 13, 19, 20)

Remarks: Elliptical placolith with a closed central area that appears very bright under crossed nicols. This species shows a straight extinction band, which occupies at least one half of the length of the elliptical central area, parallel to the major axis. Dictyococcites antarcticus Haq (1976, p. 561, Pl. 3 , Figs. 1-3, 7-8) is very similar to Dictyococcites perplexus, and is considered a junior synonym.

Dictyococcites productus (Kamptner, 1963, p. 172, Pl. 8, Figs. 42, 44) Back$\operatorname{man}(1980$, p. 49, Pl. 4, Figs. 1-3, 6-7).

Remarks: Small placolith (usually range between 3 and $4 \mu \mathrm{m}$ ) with a closed or nearly closed elliptical central area, and a median furrow. This species differs from Dictyococcites perplexus by having a smaller size and a less well-developed central furrow.

Discoaster exilis Martini and Bramlette (1963, p. 852, PI. 104, Figs. 1-3).

Remarks: This species is characterized by slender rays with faint ridges slightly off-centered from the median of the rays, and a constriction below the bifurcations that gives rise to two short branches. Roth (1974) found this species to be restricted to the middle Miocene in the northwestern Indian Ocean. 
Discoaster adamanteus Bramlette and Wilcoxon (1967, p. 108, Pl. 7, Fig. 6). Discoaster brouweri Tan (1927, p. 20, text-Figs. 28a-28b) emend. Bramlette and Riedel (1954, p. 402, Pl. 39, Fig. 12, text-Figs. 3a-3b).

Discoaster challengeri Bramlette and Riedel (1954, p. 401, Pl. 39, Fig. 10).

Discoaster deflandrei Bramlette and Riedel (1954, p. 399, Pl. 39, Fig. 6, text-Figs. 1a-1c).

Discoaster kugleri Martini and Bramlette (1963, p. 853, Pl. 102, Figs. 11-13). Discoaster sp.

Remark: This category includes all the discoasters that are not identifiable to the species level due to strong etching, fragmentation, or overgrowth.

Discoaster stellulus Gartner (1967, p. 3, Pl. 4, Figs. 1-3).

Discoaster variabilis Martini and Bramlette (1963, p. 854, Pl. 104, Figs. 4-9).

Emiliania huxleyi (Lohman, 1902, p. 129-130, PI. 4, Figs. 1-9, PI. 6, Fig. 69)

Hay and Mohler in Hay et al. (1967).

Gephyrocapsa caribbeanica Boudreaux and Hay in Hay et al. (1967, p. 447,

Pl. 12-13, Figs. 1-4).

Remarks: A species of Gephyrocapsa about $3 \mu \mathrm{m}$ or larger in size, with a bridge angle ranging from $50^{\circ}$ to $85^{\circ}$ with the short axis of the coccolith. This species has a smaller central opening than Gephyrocapsa oceanica. The following species, only recognizable in the electron microscope were most likely included in G. caribbeanica: Gephyrocapsa margerelii Bréhéret, Gephyrocapsa muellerae Bréhéret, Gephyrocapsa lumina Bukry, and some Gephyrocapsa rota Samtleben.

Gephyrocapsa oceanica Kamptner (1943, p. 43-49).

Remarks: A species of Gephyrocapsa about $3 \mu \mathrm{m}$ or larger in size, with a bridge angle ranging from $5^{\circ}$ to $45^{\circ}$ with the short axis of the coccolith, and a relatively large central opening. The following species that can only be identified in the electron microscope were probably included in this taxon: Gephyrocapsa omega Bukry (=Gephyrocapsa parallela Hay and Beaudry).

\section{Gephyrocapsa small}

Remarks: Any Gephyrocapsa species smaller than $3 \mu \mathrm{m}$. A small percentage of minute Gephyrocapsa oceanica and Gephyrocapsa caribbeanica may have been put into the small Gephyrocapsa group because it is not possible to consistently determine the angle of the bridge in specimens less than $3 \mu \mathrm{m}$ in size due to limitation of resolution in light microscopy.

Helicosphaera ampliaperta Bramlette and Wilcoxon (1967, p. 105, Pl. 6, Figs. 1-4).

Remarks: This species has a broadly elliptical shape with a biconvex central opening. It differs from Helicosphaera carteri, Helicosphaera recta and Helicosphaera perch-nielseniae by the lack of a bridge, which divides the central opening into two.

Helicosphaera carteri (Wallich, 1877, p. 348, Pl. 17, Figs. 3-4, 6-7, 17) Kamptner (1954, p. 21, 73, Figs. 17-19).

Helicosphaera perch-nielseniae (Haq, 1971, p. 116, Pl. 10, Figs. 5-7) Jafar and Martini (1975, p. 391).

Remarks: The terminal flange of this species forms an acute angle in axial view. Helicosphaera perch-nielseniae differs from Helicosphaera recta and Helicosphaera obliqua by the lack of openings in the central area and the acute angle of the terminal flange. The latter two species have a terminal flange with a rectangular outline.

Pontosphaera discopora Schiller (1925, p. 11, Pl. 1, Fig. 4) emend. Burns (1973, p. 151, Pl. 1, Fig. 6).

Pontosphaera distincta (Bramlette and Sullivan, 1961, p. 141, Pl. 2, Figs. 8a-8b, 9a-9c) Burns (1973, p. 153, Pl. 2, Figs. 2-3).

Pontosphaera multipora (Kamptner, 1948, p. 5, Pl. 1, Fig. 9) Roth (1970, p. 860) emend. Burns (1973, p. 151-153).

Pontosphaera pacifica Burns (1973, p. 150-151, PI. 1, Figs. 4-5) Pontosphaera sp.

Remark: This category includes all pontosphaerid rims without central structure.

Pseudoemiliania lacunosa (Kamptner, 1963, p. 172, Pl. 9, Fig. 50) Gartner (1969, p. 598, Pl. 2, Figs. 9-10).

Remarks: Bukry (1973) split Pseudoemiliania lacunosa into two species, Emiliania annula and Emiliania ovata, having a circular shape and oval shape, respectively. These two varieties were not separated because they have similar stratigraphic ranges, and a considerable intergradation in morphology (Rahman and Roth, 1989). Following Gartner (1977) and Backman (1980), P. lacunosa is considered a valid name and the two varieties, E. annula and $E$. ovata, are considered conspecific and subjective junior synonyms of $P$. lacunosa.

Reticulofenestra pseudoumbilica (Gartner, 1967, p. 4, P1. 6) Gartner (1969, p. 598, Pl. 2, Fig. 4).

Remarks: A species of Reticulofenestra larger than $6 \mu \mathrm{m}$. The differentiation of this species under the light microscope from other Reticulofenestra in the Pliocene is based on size. This criterion is difficult to use because of specimens that are transitional in size. Reticulofenestra pseudoumbilica typically consists of forms ranging in size from 5 to $10 \mu \mathrm{m}$, with the majority of forms ranging from 6 to $8 \mu \mathrm{m}$ (Backman and Shackleton, 1983).

\section{Reticulofenestra small}

Remarks: Backman (1980) showed that it is impossible to distinguish Neogene reticulofenestrids at the species level even with multivariate statistical techniques. However, he clearly showed two size groups, one larger and the other smaller than $5 \mu \mathrm{m}$. The latter group includes such species as Reticulofenestra haqii Backman, Reticulofenestra minutula (Gartner) Hac and Berggren, Reticulofenestra minuta Roth, and is here referred to as "Reticulofenestra small." The reticulofenestrids that are equal to or larger than $6 \mu \mathrm{m}$ are assigned to Reticulofenestra pseudoumbilica.

Sphenolithus abies Deflandre in Deflandre and Fert (1954, p. 164, Pl. 10 , Figs. 1-4)

Sphenolithus compactus Backman (1980, p. 59-60, Pl. 3, Figs. 20-21).

Remarks: Sphenolithus compactus differs from Sphenolithus neoabies, Sphenolithus abies, and Sphenolithus moriformis by having parallel sides in side view, and the lack of a long apical spine. S. compactus has a smooth distal outline under the light microscope. This species is comparable in size to $S$. neoabies, but it is much smaller than $S$. abies and $S$. moriformis.

Sphenolithus heteromorphus Deflandre in Deflandre and Fert (1954, p. 1785-

1787, Figs. 1-2); Bramlette and Wilcoxon (1967, p. 122-124, Pl. 2,

Figs. 6-9).

Remarks: Sphenolithus heteromorphus is characterized by a relatively long robust apical spine that is strongly birefringent at the $45^{\circ}$ position and dark at the parallel position under crossed nicols. It differs from Sphenolithus abies and Sphenolithus moriformis by a long robust apical spine and from Sphenolithus belemnos Bramlette and Wilcoxon by the taller and less conical proximal column and a narrower apical spine. S. heteromorphus is a solution-resistant species, and is often identifiable even in poorly preserved assemblages.

Sphenolithus moriformis (Brönnimann and Stradner, 1960, p. 368, Figs. 11-16) Bramlette and Wilcoxon (1967a, p. 124-126, Pl. 3, Figs. 1-6).

Remarks: Sphenolithus moriformis is more robust, less conical, and more birefringent than Sphenolithus abies. It differs from Sphenolithus neoabies by having a larger size and stronger birefringence.

Sphenolithus neoabies Bukry and Bramlette (1969, p. 140, Pl. 3, Figs. 9-11).

Remarks: This species of Sphenolithus is relatively small, and lacks the prominent apical spine typical of most species of the genus.

Sphenolithus umbrellus (Bukry, 1971, p. 50, Pl. 3, Figs. 10-13) Aubry and Knüttel in Knüttel (1986, p. 279, Pl. 5, Figs. 1-2, 5-10).

Remarks: Sphenolithus umbrellus was provisionally assigned to the genus Catinaster, which is unacceptable for the reasons stated in Knüttel (1986). This species is similar to other species of Sphenolithus in terms of morphological and optical characteristics, and differs from them only by the lack of an apical spine. S. umbrellus ranges from the lowermost part of the upper Miocene (Rahman and Roth, 1989) to upper Oligocene (Bukry, 1971; Knüttel, 1986).

Syracosphaera histrica Kamptner (1941, p. 84, 104, Pl. 6, Figs. 65-68).

Remark: This central area of Syracosphaera histrica can be distinguished from all other species of Syracosphaera by the presence of a characteristic hourglass-shaped extinction pattern.

Thoracosphaera heimii (Lohmann, 1919, p. 117, Fig. 29) Kamptner (1954, p. $40-42$, Figs. 41-42).

Thoracosphaera saxea Stradner (1961, p. 84, Fig. 71).

Triquetrorhabdulus rugosus Bramlette and Wilcoxon (1967, p. 128, Pl. 9, Figs. 17-18).

Umbilicosphaera sibogae (Weber van Bosse, 1901, p. 137, 140, Pl. 17, Figs. 1-2) Gaarder (1970, p. 122-126, Figs. 9c-9d). 
APPENDIX B

List of Barren Samples

\begin{tabular}{|c|c|c|c|c|}
\hline Site 794 & Site 795 & Site 796 & Site 797 & Site 797 \\
\hline Hole 794A & Hole 795A & Hole 796A & Hole 797A & Hole $797 \mathrm{~B}$ \\
\hline $794 \mathrm{~A}-1 \mathrm{H}-1,74-75 \mathrm{~cm}$ & $795 \mathrm{~A}-1 \mathrm{H}-1,108-109 \mathrm{~cm}$ & $796 \mathrm{~A}-1 \mathrm{H}-1,85-86 \mathrm{~cm}$ & $797 \mathrm{~A}-11 \mathrm{H}-4,26-27 \mathrm{~cm}$ & 797B-34X-2, $24-25 \mathrm{~cm}$ \\
\hline $794 \mathrm{~A}-71 \mathrm{H}-2,74-75 \mathrm{~cm}$ & $795 \mathrm{~A}-1 \mathrm{H}-3,89-90 \mathrm{~cm}$ & $796 \mathrm{~A}-1 \mathrm{H}-2,43-44 \mathrm{~cm}$ & 797A-1H-CC & $797 \mathrm{~B}-34 \mathrm{X}-4,27-28 \mathrm{~cm}$ \\
\hline $794 \mathrm{~A}-1 \mathrm{H}-3,74-75 \mathrm{~cm}$ & $795 \mathrm{~A}-1 \mathrm{H}-4,62-63 \mathrm{~cm}$ & $796 \mathrm{~A}-1 \mathrm{H}-3,85-86 \mathrm{~cm}$ & Hole 797B & 797B-34X-5, 129-130 cm \\
\hline $794 \mathrm{~A}-1 \mathrm{H}-4,76-77 \mathrm{~cm}$ & 795A-1H-CC & 796A-1H-CC & 797B-1H-1, 134-136 cm & 797B-34X-5, 145-146 cm \\
\hline 794A-1H-CC & $795 \mathrm{~A}-2 \mathrm{H}-1,81-82 \mathrm{~cm}$ & $796 \mathrm{~A}-2 \mathrm{H}-1,60-61 \mathrm{~cm}$ & 797B-1H-2, 13-15 cm & 797B-34X-CC \\
\hline $794 \mathrm{~A}-2 \mathrm{H}-1,74-75 \mathrm{~cm}$ & $795 \mathrm{~A}-2 \mathrm{H}-3,12-13 \mathrm{~cm}$ & $796 \mathrm{~A}-2 \mathrm{H}-2,60-61 \mathrm{~cm}$ & $797 \mathrm{~B}-1 \mathrm{H}-2,44-46 \mathrm{~cm}$ & 797B-35X-2, $24-25 \mathrm{~cm}$ \\
\hline $794 \mathrm{~A}-2 \mathrm{H}-2,74-75 \mathrm{~cm}$ & $795 \mathrm{~A}-2 \mathrm{H}-3,23-24 \mathrm{~cm}$ & $796 \mathrm{~A}-2 \mathrm{H}-3,60-61 \mathrm{~cm}$ & 797B-1H-3, $134-135 \mathrm{~cm}$ & 797B-35X-4, 24-25 cm \\
\hline $794 \mathrm{~A}-2 \mathrm{H} \cdot 3,74-75 \mathrm{~cm}$ & 795A-2H-CC & $796 \mathrm{~A}-2 \mathrm{H}-4,60-61 \mathrm{~cm}$ & $797 \mathrm{~B}-1 \mathrm{H}-4,104-105 \mathrm{~cm}$ & 797B-35X-CC \\
\hline $794 \mathrm{~A}-2 \mathrm{H}-4,74-75 \mathrm{~cm}$ & $795 \mathrm{~A}-3 \mathrm{H}-2,23-24 \mathrm{~cm}$ & $796 \mathrm{~A}-2 \mathrm{H}-5,60 \cdot 61 \mathrm{~cm}$ & 797B-1H-CC & 797B-36X-CC \\
\hline $794 \mathrm{~A}-2 \mathrm{H}-5,74-75 \mathrm{~cm}$ & $795 \mathrm{~A}-3 \mathrm{H}-2,85 \cdot 86 \mathrm{~cm}$ & 796A-2H-CC & $797 \mathrm{~B}-2 \mathrm{H}-1,27-28 \mathrm{~cm}$ & 797B-37X-2, $21-22 \mathrm{~cm}$ \\
\hline $794 \mathrm{~A}-2 \mathrm{H}-6,74-75 \mathrm{~cm}$ & $795 \mathrm{~A}-3 \mathrm{H}-4,64-65 \mathrm{~cm}$ & $796 \mathrm{~A}-3 \mathrm{H}-1,40-41 \mathrm{~cm}$ & $797 \mathrm{~B}-2 \mathrm{H}-2,27-28 \mathrm{~cm}$ & 797B-37X-4, 21-22 cm \\
\hline 794A-2H-CC & $795 \mathrm{~A}-3 \mathrm{H}-5,5-6 \mathrm{~cm}$ & $796 \mathrm{~A}-3 \mathrm{H}-2,40-41 \mathrm{~cm}$ & $797 \mathrm{~B}-2 \mathrm{H}-3,14-16 \mathrm{~cm}$ & 797B-37X-CC \\
\hline $794 \mathrm{~A}-3 \mathrm{H}-1,73-74 \mathrm{~cm}$ & $795 \mathrm{~A} \cdot 3 \mathrm{H} \cdot 5,75-76 \mathrm{~cm}$ & $796 \mathrm{~A}-4 \mathrm{H}-1,40-41 \mathrm{~cm}$ & $797 \mathrm{~B}-2 \mathrm{H}-3,27-28 \mathrm{~cm}$ & $7978-38 \times-2,8-9 \mathrm{~cm}$ \\
\hline $794 \mathrm{~A}-3 \mathrm{H}-3,73 \cdot 74 \mathrm{~cm}$ & $795 \mathrm{~A}-3 \mathrm{H} \cdot 6,138-139 \mathrm{~cm}$ & $796 \mathrm{~A}-4 \mathrm{H} \cdot 2,40-41 \mathrm{~cm}$ & $797 \mathrm{~B}-2 \mathrm{H}-4,14-16 \mathrm{~cm}$ & 797B-38X-CC \\
\hline $794 \mathrm{~A}-3 \mathrm{H}-4,73-74 \mathrm{~cm}$ & 795A-3H-CC & $796 \mathrm{~A}-4 \mathrm{H}-3,40-41 \mathrm{~cm}$ & $797 \mathrm{~B}-2 \mathrm{H}-4,27-28 \mathrm{~cm}$ & (797B-39X-CC, $(21-22 \mathrm{~cm})$ \\
\hline $794 \mathrm{~A}-3 \mathrm{H}-6,73-74 \mathrm{~cm}$ & $795 \mathrm{~A}-4 \mathrm{H}-1,126-127 \mathrm{~cm}$ & $796 \mathrm{~A}-4 \mathrm{H}-4,40-41 \mathrm{~cm}$ & $797 \mathrm{~B}-2 \mathrm{H}-5,27-28 \mathrm{~cm}$ & 797B-39X-CC \\
\hline $794 \mathrm{~A}-4 \mathrm{H}-1,73-74 \mathrm{~cm}$ & $795 \mathrm{~A}-4 \mathrm{H}-5,20-21 \mathrm{~cm}$ & $796 \mathrm{~A}-4 \mathrm{H}-5,53-54 \mathrm{~cm}$ & $797 \mathrm{~B}-2 \mathrm{H}-6,27-28 \mathrm{~cm}$ & $797 \mathrm{~B}-40 \mathrm{X}-1,22-23 \mathrm{~cm}$ \\
\hline $794 \mathrm{~A}-4 \mathrm{H}-1,116-117 \mathrm{~cm}$ & $795 \mathrm{~A}-4 \mathrm{H}-6,148-149 \mathrm{~cm}$ & $796 \mathrm{~A}-4 \mathrm{H}-6,54-55 \mathrm{~cm}$ & $797 \mathrm{~B}-2 \mathrm{H}-7,27-28 \mathrm{~cm}$ & $797 \mathrm{~B}-41 \mathrm{X}-1,20-21 \mathrm{~cm}$. \\
\hline $794 \mathrm{~A} \cdot 4 \mathrm{H}-3,74 \cdot 75 \mathrm{~cm}$ & $795 \mathrm{~A}-4 \mathrm{H}-7,26-27 \mathrm{~cm}$ & $796 \mathrm{~A}-4 \mathrm{H} \cdot \mathrm{CC}$ & 797B-2H-CC & 797B-42X-1, 20-21 cm \\
\hline $794 \mathrm{~A}-4 \mathrm{H}-4,74-76 \mathrm{~cm}$ & $795 \mathrm{~A}-4 \mathrm{H}-7,148-149 \mathrm{~cm}$ & $796 \mathrm{~A}-5 \mathrm{H} \cdot 1,33-34 \mathrm{~cm}$ & $7978-3 \mathrm{H}-2,26-27 \mathrm{~cm}$ & 797B-42X-CC \\
\hline $794 \mathrm{~A}-4 \mathrm{H}-5,72-74 \mathrm{~cm}$ & $795 \mathrm{~A}-5 \mathrm{H}-3,116-117 \mathrm{~cm}$ & $796 \mathrm{~A}-5 \mathrm{H}-2,28-29 \mathrm{~cm}$ & $797 \mathrm{~B}-3 \mathrm{H}-3,26-27 \mathrm{~cm}$ & 797B-43X-1, 20-21 cm \\
\hline 794A-4H-CC & $795 \mathrm{~A}-5 \mathrm{H}-4,83 \cdot 84 \mathrm{~cm}$ & $796 \mathrm{~A}-5 \mathrm{H}-3,45-46 \mathrm{~cm}$ & 797B-3H-4, 26-27 cm & 797B-43X-CC \\
\hline $794 \mathrm{~A}-5 \mathrm{H}-1,55-56 \mathrm{~cm}$ & 795A-5H-6, 90-91 cm & $796 \mathrm{~A}-5 \mathrm{H} \cdot 4,9-10 \mathrm{~cm}$ & 797B-3H-5, 26-27 cm & 797B-44X-1, $14-15 \mathrm{~cm}$ \\
\hline $794 \mathrm{~A}-5 \mathrm{H}-1,75-76 \mathrm{~cm}$ & 795A-5H-CC & $796 \mathrm{~A}-5 \mathrm{H} \cdot 8,47-48 \mathrm{~cm}$ & 797B-3H-6, $26-27 \mathrm{~cm}$ & 797B-44X-CC \\
\hline $794 \mathrm{~A}-5 \mathrm{H}-2,75-76 \mathrm{~cm}$ & $795 \mathrm{~A} \cdot 6 \mathrm{H} \cdot 2,85 \cdot 86 \mathrm{~cm}$ & $796 \mathrm{~A}-6 \mathrm{H}-1,20-21 \mathrm{~cm}$ & $797 \mathrm{~B}-4 \mathrm{H}-1,26-27 \mathrm{~cm}$ & $797 B-45 X-C C$ \\
\hline $794 \mathrm{~A}-5 \mathrm{H}-3,45-46 \mathrm{~cm}$ & $795 \mathrm{~A}-6 \mathrm{H}-4,94-95 \mathrm{~cm}$ & $796 \mathrm{~A}-6 \mathrm{H}-2,3-4 \mathrm{~cm}$ & $797 \mathrm{~B}-4 \mathrm{H}-2,26-27 \mathrm{~cm}$ & 797B-46X-1, $32-33 \mathrm{~cm}$ \\
\hline $794 \mathrm{~A}-5 \mathrm{H}-4,74-75 \mathrm{~cm}$ & $795 \mathrm{~A}-6 \mathrm{H}-6,88-89 \mathrm{~cm}$ & $796 \mathrm{~A}-6 \mathrm{H}-2,29-30 \mathrm{~cm}$ & $797 \mathrm{~B}-4 \mathrm{H}-3,26-27 \mathrm{~cm}$ & $797 B-46 X-1,36-47 \mathrm{~cm}$ \\
\hline $794 \mathrm{~A}-5 \mathrm{H}-5,74-75 \mathrm{~cm}$ & 795A-6H-CC & $796 \mathrm{~A}-6 \mathrm{H}-3,46-47 \mathrm{~cm}$ & $797 \mathrm{~B}-4 \mathrm{H}-5,26-27 \mathrm{~cm}$ & $7978-46 X-4,35-36 \mathrm{~cm}$ \\
\hline $794 \mathrm{~A}-5 \mathrm{H}-6,75 \cdot 76 \mathrm{~cm}$ & 795A-7H-2, 56-57 cm & $796 \mathrm{~A}-6 \mathrm{H}-4,10-11 \mathrm{~cm}$ & $797 \mathrm{~B}-4 \mathrm{H}-6,26-27 \mathrm{~cm}$ & 797B-47X-1, $41-42 \mathrm{~cm}$ \\
\hline 794A-5H-CC & $795 \mathrm{~A}-7 \mathrm{H}-3,69-70 \mathrm{~cm}$ & $796 \mathrm{~A}-6 \mathrm{H}-5,124-125 \mathrm{~cm}$ & 797B-5H-1, 26-27 cm & $7978-47 X-3,45-46 \mathrm{~cm}$ \\
\hline $794 \mathrm{~A}-6 \mathrm{H}-1,74-75 \mathrm{~cm}$ & 795A-7H-5. 81-82 cm & 796A-6H-7, 100-101 cm & 797B-5H-26-27 cm & $797 \mathrm{~B}-47 \mathrm{X}-4,45-46 \mathrm{~cm}$ \\
\hline $794 \mathrm{~A}-6 \mathrm{H}-2,74-75 \mathrm{~cm}$ & 795A-7H-6, 33-34 cm & $796 \mathrm{~A}-8 \mathrm{H}-1,33-34 \mathrm{~cm}$ & $797 \mathrm{~B}-5 \mathrm{H}-5,26-27 \mathrm{~cm}$ & $797 \mathrm{~B}-47 \mathrm{X}-4,142-143 \mathrm{~cm}$ \\
\hline $794 \mathrm{~A}-6 \mathrm{H}-3,77-78 \mathrm{~cm}$ & 795A-7H-CC & $796 \mathrm{~A}-8 \mathrm{H}-3,122 \cdot 123 \mathrm{~cm}$ & $797 \mathrm{~B}-5 \mathrm{H}-6,26-27 \mathrm{~cm}$ & $797 \mathrm{~B}-47 \mathrm{X}-5,7-8 \mathrm{~cm}$ \\
\hline $794 \mathrm{~A}-6 \mathrm{H}-4,74-75 \mathrm{~cm}$ & $795 \mathrm{~A}-8 \mathrm{H}-2,88-89 \mathrm{~cm}$ & $796 \mathrm{~A}-8 \mathrm{H}-4,122-123 \mathrm{~cm}$ & $7978-6 \mathrm{H}-1,27-28 \mathrm{~cm}$ & $797 \mathrm{~B}-47 \mathrm{X}-5,45-46 \mathrm{~cm}$ \\
\hline $794 \mathrm{~A}-6 \mathrm{H} \cdot 5,71-72 \mathrm{~cm}$ & $795 \mathrm{~A}-8 \mathrm{H}-4,80-81 \mathrm{~cm}$ & 796A-8X-CC & $7978 \cdot 6 \mathrm{H}-2,27-28 \mathrm{~cm}$ & $797 B-47 X-5,126-127 \mathrm{~cm}$ \\
\hline $794 \mathrm{~A}-6 \mathrm{H}-6,75 \cdot 76 \mathrm{~cm}$ & 795A-8H-CC & 796A-9X-1, 33-34 cm & $797 \mathrm{~B} \cdot 6 \mathrm{H}-3,27-28 \mathrm{~cm}$ & $797 \mathrm{~B}-47 \mathrm{X}-5,148-149 \mathrm{~cm}$ \\
\hline $794 \mathrm{~A}-6 \mathrm{H}-\mathrm{CC}$ & $795 \mathrm{~A}-9 \mathrm{H}-2,88-89 \mathrm{~cm}$ & $796 \mathrm{~A}-9 \mathrm{X}-2,69-70 \mathrm{~cm}$ & 797B-6H-4, $27-28 \mathrm{~cm}$ & 797B-48X-3, 49-50 cm \\
\hline $794 \mathrm{~A}-7 \mathrm{H}-1,74-75 \mathrm{~cm}$ & $795 \mathrm{~A}-9 \mathrm{H}-4,88-89 \mathrm{~cm}$ & $796 \mathrm{~A}-9 \mathrm{X}-3,69-70 \mathrm{~cm}$ & 797B-6H-5, $27-28 \mathrm{~cm}$ & $7978-48 X-3,147-148 \mathrm{~cm}$ \\
\hline $794 \mathrm{~A}-7 \mathrm{H}-4,74-75 \mathrm{~cm}$ & $795 \mathrm{~A}-9 \mathrm{H}-6,88-89 \mathrm{~cm}$ & $796 \mathrm{~A}-10 \mathrm{X}-1,32-33 \mathrm{~cm}$ & 7978-6H-6, 83-84 cm & $797 \mathrm{~B}-48 \times-4,8-9 \mathrm{~cm}$ \\
\hline 794A-7H-CC & 795A-9H-CC & 796A-10X-CC & $797 \mathrm{~B} \cdot 6 \mathrm{H} \cdot 7,27 \cdot 28 \mathrm{~cm}$ & $7978-48 X-4,35-36 \mathrm{~cm}$ \\
\hline $794 \mathrm{~A}-8 \mathrm{H}-3,74-75 \mathrm{~cm}$ & $795 \mathrm{~A}-10 \mathrm{H}-2,113-114 \mathrm{~cm}$ & $796 \mathrm{~A}-11 \mathrm{X}-1,45-56 \mathrm{~cm}$ & 797B-6H.CC & $7978-48 X-4,128-129 \mathrm{~cm}$ \\
\hline $794 \mathrm{~A}-8 \mathrm{H}-4,74-75 \mathrm{~cm}$ & $795 \mathrm{~A}-11 \mathrm{H} \cdot 1,39 \cdot 40 \mathrm{~cm}$ & $796 \mathrm{~A}-11 \mathrm{X}-2,70-71 \mathrm{~cm}$ & 797B-7H-1, 25-26 cm & $7978-48 \times-5,8-9 \mathrm{~cm}$ \\
\hline 794A-8H-CC & $795 \mathrm{~A}-11 \mathrm{H}-2,74-75 \mathrm{~cm}$ & 796A-11X-CC & 797B-7H-3, 25-26 cm & 797B-48X-5, $49.50 \mathrm{~cm}$ \\
\hline $794 \mathrm{~A}-9 \mathrm{H}-2,73-74 \mathrm{~cm}$ & $795 \mathrm{~A}-11 \mathrm{H}-5,39-40 \mathrm{~cm}$ & $796 \mathrm{~A}-12 \mathrm{X}-1,90-91 \mathrm{~cm}$ & 797B-7H-4, $25-26 \mathrm{~cm}$ & $7978-48 X-6,88-89 \mathrm{~cm}$ \\
\hline $794 \mathrm{~A}-9 \mathrm{H}-5,73-74 \mathrm{~cm}$ & $795 \mathrm{~A}-11 \mathrm{H}-\mathrm{CC}$ & $796 \mathrm{~A}-12 \mathrm{X}-5,91-92 \mathrm{~cm}$ & 797B-7H-5, 25-26 cm & $797 \mathrm{~B}-48 \mathrm{X}-\mathrm{CC}$ \\
\hline 794A-9H-CC & $795 \mathrm{~A}-12 \mathrm{H}-1,40-41 \mathrm{~cm}$ & $796 \mathrm{~A}-12 \mathrm{X}-6,50-51 \mathrm{~cm}$ & 797B-7H-6, 25-26 cm & 797B-49X-1, 25-26 cm \\
\hline $794 \mathrm{~A}-10 \mathrm{H} \cdot 3,74-75 \mathrm{~cm}$ & $795 \mathrm{~A}-12 \mathrm{H}-3,40-41 \mathrm{~cm}$ & $796 \mathrm{~A}-12 \mathrm{X}-\mathrm{CC}$ & 797B-7H-7, 25-26 cm & $7978-49 X-2,25-26 \mathrm{~cm}$ \\
\hline $794 \mathrm{~A} \cdot 10 \mathrm{H} \cdot 5,85 \cdot 86 \mathrm{~cm}$ & $795 \mathrm{~A}-12 \mathrm{H}-5,40-41 \mathrm{~cm}$ & $796 \mathrm{~A}-14 \mathrm{X}-1,73-74 \mathrm{~cm}$ & 797B-7H-CC & $7978-49 X-3,25-26 \mathrm{~cm}$ \\
\hline $794 \mathrm{~A}-10 \mathrm{H}-\mathrm{CC}$ & $795 \mathrm{~A}-12 \mathrm{H}-\mathrm{CC}$ & $796 \mathrm{~A}-14 \mathrm{X}-4,79-80 \mathrm{~cm}$ & $797 \mathrm{~B}-8 \mathrm{H}-1,27-28 \mathrm{~cm}$ & 797B-49X-4, 25-26 cm \\
\hline $794 \mathrm{~A}-11 \mathrm{H}-5,73-74 \mathrm{~cm}$ & $795 \mathrm{~A}-13 \mathrm{H}-1,86-87 \mathrm{~cm}$ & 796A-14X-CC & $797 \mathrm{~B}-8 \mathrm{H}-3,27-28 \mathrm{~cm}$ & 797B-49X-5, $25-26 \mathrm{~cm}$ \\
\hline 794A-11H-CC & $795 \mathrm{~A}-13 \mathrm{H}-4,81-82 \mathrm{~cm}$ & $796 \mathrm{~A}-15 \mathrm{X}-1,72-73 \mathrm{~cm}$ & $7978-8 \mathrm{H}-4,27-28 \mathrm{~cm}$ & 797B-49X-6, 25-26 cm \\
\hline $794 \mathrm{~A}-12 \mathrm{H}-2,73-74 \mathrm{~cm}$ & $795 \mathrm{~A}-13 \mathrm{H}-6,84-85 \mathrm{~cm}$ & $796 \mathrm{~A}-15 \mathrm{X}-3,72-73 \mathrm{~cm}$ & 797B-8H-5, 27-28 cm & 797B-49X-CC \\
\hline $794 \mathrm{~A}-12 \mathrm{~B}-5,73-74 \mathrm{~cm}$ & $795 \mathrm{~A}-13 \mathrm{H}-\mathrm{CC}$ & 796A-15X-CC & $7978-8 \mathrm{H}-7,26-27 \mathrm{~cm}$ & 797B-50X-1, $15-16 \mathrm{~cm}$ \\
\hline $794 \mathrm{~A}-12 \mathrm{H}-\mathrm{CC}$ & $795 \mathrm{~A}-14 \mathrm{H}-2,105-106 \mathrm{~cm}$ & $796 \mathrm{~A}-16 \mathrm{X}-1,73-74 \mathrm{~cm}$ & 7978-9H-1, 29-30 cm & $797 \mathrm{~B}-51 \mathrm{X}-1,25-26 \mathrm{~cm}$ \\
\hline
\end{tabular}


APPENDIX B (continued).

\begin{tabular}{|c|c|c|c|c|}
\hline Site 794 & Site 795 & Site 796 & Site 797 & Site 797 \\
\hline Hole 794A & Hole 795A & Hole 796A & Hole 797B & Hole 797B \\
\hline $794 \mathrm{~A}-13 \mathrm{H}-2,71-72 \mathrm{~cm}$ & $795 \mathrm{~A}-14 \mathrm{H}-4,37-38 \mathrm{~cm}$ & $796 \mathrm{~A}-16 \mathrm{X}-3,15-16 \mathrm{~cm}$ & $797 \mathrm{~B}-9 \mathrm{H}-2,29-30 \mathrm{~cm}$ & $797 \mathrm{~B}-51 \mathrm{X}-2,25-26 \mathrm{~cm}$ \\
\hline $794 \mathrm{~A}-13 \mathrm{H}-5,73-75 \mathrm{~cm}$ & $795 \mathrm{~A}-14 \mathrm{H}-4,91-92 \mathrm{~cm}$ & 796A-16X-CC & $797 \mathrm{~B}-9 \mathrm{H}-3,29-30 \mathrm{~cm}$ & $797 \mathrm{~B}-51 \mathrm{X}-4,25-26 \mathrm{~cm}$. \\
\hline $794 \mathrm{~A}-13 \mathrm{H}-\mathrm{CC}$ & $795 \mathrm{~A}-14 \mathrm{H}-4,93-94 \mathrm{~cm}$ & $796 \mathrm{~A}-17 \mathrm{X}-1,70-71 \mathrm{~cm}$ & 797B-9H-4, 29-30 cm & 797B-51X-6, 25-26 cm \\
\hline $794 \mathrm{~A}-14 \mathrm{H}-2,72-73 \mathrm{~cm}$ & $795 \mathrm{~A}-14 \mathrm{H}-6,44-46 \mathrm{~cm}$ & $796 \mathrm{~A}-17 \mathrm{X}-3,14-15 \mathrm{~cm}$ & 797B-9H-5, 54-55 cm & $797 B-52 X-1,25-26 \mathrm{~cm}$ \\
\hline $794 \mathrm{~A}-14 \mathrm{H}-5,73-74 \mathrm{~cm}$ & $795 \mathrm{~A}-14 \mathrm{H}-\mathrm{CC}$ & 796A-17X-CC & 797B-9H-6, 29-30 cm & 797B-52X-2, $25-26 \mathrm{~cm}$ \\
\hline $794 \mathrm{~A}-14 \mathrm{H}-\mathrm{CC}$ & $795 \mathrm{~A}-15 \mathrm{H}-2,106-107 \mathrm{~cm}$ & $796 \mathrm{~A}-18 \mathrm{X}-2,70-71 \mathrm{~cm}$ & $797 \mathrm{~B}-9 \mathrm{H}-7,29-30 \mathrm{~cm}$ & $797 \mathrm{~B}-52 \mathrm{X}-3,25-26 \mathrm{~cm}$ \\
\hline $794 \mathrm{~A}-15 \mathrm{H}-4,73-74 \mathrm{~cm}$ & $795 \mathrm{~A}-15 \mathrm{H}-5,45-46 \mathrm{~cm}$ & $796 \mathrm{~A}-18 \mathrm{X}-4,70-71 \mathrm{~cm}$ & $797 \mathrm{~B}-10 \mathrm{H}-1,25-26 \mathrm{~cm}$ & 797B-52X-4, 25-26 cm \\
\hline $794 \mathrm{~A}-15 \mathrm{H}-\mathrm{CC}$ & $795 \mathrm{~A}-15 \mathrm{H}-\mathrm{CC}$ & $796 \mathrm{~A}-18 \mathrm{X}-6,70-71 \mathrm{~cm}$ & $797 \mathrm{~B}-10 \mathrm{H}-2,25-26 \mathrm{~cm}$ & $797 B-52 X-5,25-26 \mathrm{~cm}$ \\
\hline $794 \mathrm{~A}-16 \mathrm{X}-4,73-74 \mathrm{~cm}$ & $795 \mathrm{~A}-16 \mathrm{H}-2,89-90 \mathrm{~cm}$ & 796A-18X-CC & $797 \mathrm{~B}-10 \mathrm{H}-3,25-26 \mathrm{~cm}$ & $7978-52 X-6,25-26 \mathrm{~cm}$ \\
\hline 794A-16H-CC & $795 \mathrm{~A}-16 \mathrm{H}-3,63-64 \mathrm{~cm}$ & $796 \mathrm{~A}-19 \mathrm{X}-2,70-71 \mathrm{~cm}$ & $797 \mathrm{~B}-10 \mathrm{H}-4,25-26 \mathrm{~cm}$ & 797B-52X-7, 25-26 cm \\
\hline $794 \mathrm{~A}-17 \mathrm{X}-4,73-74 \mathrm{~cm}$ & $795 \mathrm{~A}-16 \mathrm{H}-4,58-59 \mathrm{~cm}$ & $796 \mathrm{~A}-19 \mathrm{X}-4,70-71 \mathrm{~cm}$ & $797 \mathrm{~B}-10 \mathrm{H}-5,25-26 \mathrm{~cm}$ & 797B-52X-CC \\
\hline 794A-17H-CC & 795A-16H-CC & 796A-19X-CC & $797 \mathrm{~B}-10 \mathrm{H}-6,25-26 \mathrm{~cm}$ & Hole $797 \mathrm{C}$ \\
\hline 794A-18H-CC & 795A-17H-CC & $796 \mathrm{~A}-20 \mathrm{X}-1,39 \cdot 40 \mathrm{~cm}$ & $797 \mathrm{~B}-10 \mathrm{H}-7,25-26 \mathrm{~cm}$ & $797 \mathrm{C}-14 \mathrm{R}-1,42-44 \mathrm{~cm}$ \\
\hline $794 \mathrm{~A}-19 \mathrm{X}-1,3-4 \mathrm{~cm}$ & $795 \mathrm{~A}-18 \mathrm{H}-2,40-41 \mathrm{~cm}$ & $796 \mathrm{~A}-20 \mathrm{X}-2,39-40 \mathrm{~cm}$ & 797B-10H, CC & $797 \mathrm{C}-18 \mathrm{R}-1,42-43 \mathrm{~cm}$ \\
\hline $794 \mathrm{~A}-19 \mathrm{X}-3,30-31 \mathrm{~cm}$ & $795 \mathrm{~A}-18 \mathrm{H}-6,40-41 \mathrm{~cm}$ & 796A-20X-CC & $797 \mathrm{~B}-11 \mathrm{H}-1,26-27 \mathrm{~cm}$ & 797C-19R-5, $110-111 \mathrm{~cm}$ \\
\hline $794 \mathrm{~A}-19 \mathrm{X}-4,73-74 \mathrm{~cm}$ & 795A-18H-CC & $796 \mathrm{~A}-21 \mathrm{X}-1,39-40 \mathrm{~cm}$ & $797 \mathrm{~B}-11 \mathrm{H}-2,26-27 \mathrm{~cm}$ & $797 \mathrm{C}-19 \mathrm{R}-6,28-30 \mathrm{~cm}$ \\
\hline 794A-19X-CC & $795 \mathrm{~A}-19 \mathrm{H}-2,40-41 \mathrm{~cm}$ & $796 \mathrm{~A}-21 \mathrm{X}-3,39-40 \mathrm{~cm}$ & $797 \mathrm{~B}-11 \mathrm{H}-3,25-26 \mathrm{~cm}$ & $797 \mathrm{C}-20 \mathrm{R}-2,42-43 \mathrm{~cm}$ \\
\hline $794 \mathrm{~A}-20 \mathrm{X}-4,74-75 \mathrm{~cm}$ & $795 \mathrm{~A}-19 \mathrm{H}-6,40-41 \mathrm{~cm}$ & $796 \mathrm{~A}-21 X-5,39-40 \mathrm{~cm}$ & $797 \mathrm{~B}-11 \mathrm{H}-4,25-26 \mathrm{~cm}$ & 797C-23A-CC \\
\hline 794A-20X-CC & $795 \mathrm{~A}-19 \mathrm{H}-\mathrm{CC}$ & 796A-21X-CC & $797 \mathrm{~B}-11 \mathrm{H}-5,25-26 \mathrm{~cm}$ & $797 \mathrm{C}-25 \mathrm{R}-1,62-63 \mathrm{~cm}$ \\
\hline $794 \mathrm{~A}-21 \mathrm{X}-4,74-75 \mathrm{~cm}$ & $795 \mathrm{~A}-21 \mathrm{X}-2,40-41 \mathrm{~cm}$ & $796 \mathrm{~A}-22 \mathrm{X}-1,40-41 \mathrm{~cm}$ & 797B-11H-6, $25-26 \mathrm{~cm}$ & 797C-25R-2, $142-143 \mathrm{~cm}$ \\
\hline 794A-21X-CC & $795 \mathrm{~A}-21 \mathrm{X}-6,40-41 \mathrm{~cm}$ & $796 \mathrm{~A}-22 \mathrm{X}-3,38-39 \mathrm{~cm}$ & 797B-11H-7, 26-27 cm & $797 \mathrm{C}-25 \mathrm{R}-4,86 \mathrm{~cm}$ \\
\hline 794A-22X-CC & 795A-21X-CC & $796 \mathrm{~A}-22 \mathrm{X}-5,40-41 \mathrm{~cm}$ & 797B-11H-CC & 797C-27R-CC \\
\hline $794 A-23 X-C C$ & $795 \mathrm{~A}-22 \mathrm{X}-1,46-47 \mathrm{~cm}$ & 796A-22X-CC & $797 \mathrm{~B}-12 \mathrm{H}-1,25-26 \mathrm{~cm}$ & $797 \mathrm{C}-30 \mathrm{R}-4,86 \mathrm{~cm}$ \\
\hline 794A-24X-CC & $795 \mathrm{~A}-22 \mathrm{X}-2,30-31 \mathrm{~cm}$ & $796 \mathrm{~A}-23 \mathrm{X}-1,37-38 \mathrm{~cm}$ & $797 \mathrm{~B}-12 \mathrm{H}-2,25-26 \mathrm{~cm}$ & $797 C-31 R-5,68-69 \mathrm{~cm}$ \\
\hline $794 A-25 X-C C$ & $795 \mathrm{~A}-22 \mathrm{X}-4,40-41 \mathrm{~cm}$ & $796 \mathrm{~A}-23 \mathrm{X}-3,37-38 \mathrm{~cm}$ & $797 \mathrm{~B}-12 \mathrm{H}-4,25-26 \mathrm{~cm}$ & 797C-33R-2,101-102 cm \\
\hline 794A-26X-CC & $795 \mathrm{~A}-22 \mathrm{X}-6,40-41 \mathrm{~cm}$ & $796 \mathrm{~A}-23 \mathrm{X}-5,40-41 \mathrm{~cm}$ & $797 \mathrm{~B}-12 \mathrm{H}-5,25-26 \mathrm{~cm}$ & $797 \mathrm{C}-33 \mathrm{R}-3,67-68 \mathrm{~cm}$ \\
\hline 794A-27X-CC & 795A-22X-CC & 796A-23X-CC & 797B-12H-6, 25-26 cm & $797 \mathrm{C}-34 \mathrm{R}-1,112-113 \mathrm{~cm}$ \\
\hline $794 A-28 X-C C$ & $795 \mathrm{~A}-25 \mathrm{X}-1,46-47 \mathrm{~cm}$ & $796 \mathrm{~A}-24 \mathrm{X}-1,39-40 \mathrm{~cm}$ & 797B-12H-CC & $797 C-34 R-6,141-142 \mathrm{~cm}$ \\
\hline 794A-29X-CC & 795A-25X-CC & $796 A-24 X-C C$ & $797 \mathrm{~B}-13 \mathrm{H}-1,26-27 \mathrm{~cm}$ & $797 \mathrm{C}-34 \mathrm{R}-7,27-28 \mathrm{~cm}$ \\
\hline $794 \mathrm{~A}-30 \times-3,74-75 \mathrm{~cm}$ & $795 A-26 X-1,45-46 \mathrm{~cm}$ & $796 \mathrm{~A}-25 \mathrm{X}-1,39-40 \mathrm{~cm}$ & $797 \mathrm{~B}-13 \mathrm{H}-2,26-27 \mathrm{~cm}$ & 797C-34R-CC \\
\hline $794 A-30 X-C C$ & $795 \mathrm{~A}-26 \mathrm{X}-6,40-46 \mathrm{~cm}$ & 796A-25X-CC & $797 \mathrm{~B}-13 \mathrm{H}-3,26-27 \mathrm{~cm}$ & 797C-35R-CC \\
\hline 794A-31X-CC & 795A-26X-CC & $796 \mathrm{~A}-26 \mathrm{X}-1,20-21 \mathrm{~cm}$ & $797 \mathrm{~B}-13 \mathrm{H}-4,26-27 \mathrm{~cm}$ & $797 \mathrm{C}-36 \mathrm{R}-3,48-49 \mathrm{~cm}$ \\
\hline 794A-32X-CC & $795 A-27 X-1,46-47 \mathrm{~cm}$ & 796A-26X-CC & $797 \mathrm{~B}-13 \mathrm{H}-5,26-27 \mathrm{~cm}$ & 797C-37R-4, 61-62 cm \\
\hline 794A-33X-1, $143-144 \mathrm{~cm}$ & $795 \mathrm{~A}-27 \mathrm{X}-5,38-39 \mathrm{~cm}$ & 796A-27X-CC & $797 \mathrm{~B}-13 \mathrm{H} \cdot 6,26-27 \mathrm{~cm}$ & 797C-37R-6, 90-91 cm \\
\hline $794 \mathrm{~A}-33 \mathrm{X}-4,74-75 \mathrm{~cm}$ & 795A-27X-CC & HOLE 796B & 797B-13H-7, 26-27 cm & $797 \mathrm{C}-41 \mathrm{R}-2,145-146 \mathrm{~cm}$ \\
\hline 794A-33X-CC & $795 \mathrm{~A}-29 \mathrm{X}-3,40-41 \mathrm{~cm}$ & 796B-1R-CC & 797B-13H-CC & $797 C-41 R-C C$ \\
\hline 794A-34X-CC & 795A-29X-CC & $796 \mathrm{~B}-2 \mathrm{~W}-2,8-9 \mathrm{~cm}$ & $797 \mathrm{~B}-14 \mathrm{H}-2,26-27 \mathrm{~cm}$ & \\
\hline $794 A-35 X-4,64-65 \mathrm{~cm}$ & $795 \mathrm{~A}-30 \mathrm{X}-1,40-41 \mathrm{~cm}$ & 796B-2W-CC & $797 \mathrm{~B}-14 \mathrm{H}-3,26-27 \mathrm{~cm}$ & \\
\hline 794A-35X-CC & $795 \mathrm{~A}-30 \mathrm{X}-3,40-41 \mathrm{~cm}$ & 796B-3R-1, 71-72 cm & $797 \mathrm{~B}-14 \mathrm{H}-4,26-27 \mathrm{~cm}$ & \\
\hline $794 A-36 X-4,45-46 \mathrm{~cm}$ & 795A-30X-CC & 796B-3R-2, $71-72 \mathrm{~cm}$ & $797 \mathrm{~B}-14 \mathrm{H}-5,26-27 \mathrm{~cm}$ & \\
\hline 794A-36X-CC & $795 \mathrm{~A}-31 \mathrm{X}-1,40-41 \mathrm{~cm}$ & 796B-3R-CC & $797 \mathrm{~B}-14 \mathrm{H}-6,26-27 \mathrm{~cm}$ & \\
\hline $794 A-37 X-2,55-56 \mathrm{~cm}$ & $795 \mathrm{~A}-31 \mathrm{X}-3,40-41 \mathrm{~cm}$ & 796B-4R-2, $67-68 \mathrm{~cm}$ & $797 \mathrm{~B}-15 \mathrm{H}-1,28-29 \mathrm{~cm}$ & \\
\hline 794A-37X-CC & $795 A-31 X-5,56-57 \mathrm{~cm}$ & 7968-5R-1, 30-31 cm & $797 \mathrm{~B}-15 \mathrm{H}-2,26-27 \mathrm{~cm}$ & \\
\hline Hole 794B & 795A-31X-CC & 796B-5R-3, 61-62 cm & $797 \mathrm{~B}-15 \mathrm{H}-3,26-27 \mathrm{~cm}$ & \\
\hline 794B-1R-1, 110-111 cm & $795 \mathrm{~A}-34 \mathrm{X}-1,40-41 \mathrm{~cm}$ & 796B-5R-CC & $797 \mathrm{~B}-15 \mathrm{H}-4,26-27 \mathrm{~cm}$ & \\
\hline 794B-1R-2, $110-111 \mathrm{~cm}$ & $795 \mathrm{~A}-34 \mathrm{X}-3,40-41 \mathrm{~cm}$ & 796B-6R-1, 55-56 cm & $797 \mathrm{~B}-15 \mathrm{H}-5,26-27 \mathrm{~cm}$ & \\
\hline 794B-2R-1, 110-111 cm & $795 \mathrm{~A}-34 \mathrm{X}-5,56-57 \mathrm{~cm}$ & 796B-6R-CC & $797 \mathrm{~B}-15 \mathrm{H}-6,26-27 \mathrm{~cm}$ & \\
\hline 794B-3R-CC & 795A-34X-CC & 796B-7R-1, 20-21 cm & 797B-15H-7, 26-27 cm & \\
\hline 794B-4R-1, 46-47 cm & $795 A-35 X-5,56-57 \mathrm{~cm}$ & 796B-7R-1, 55-56 cm & 797B-15H-CC & \\
\hline 794B-4A-CC & 795A-35X-CC & 796B-7R-1, $119-120 \mathrm{~cm}$ & 797B-16H-CC & \\
\hline 794B-5R-1, 3-4 cm & 795A-36X-CC & 796B-9R-CC & 797B-17H-1, 25-26 cm & \\
\hline 794B-5R-CC & 795A-37X-CC & 796B-10R-1, 10-11 cm & 797B-17H-5, 29-30 cm & \\
\hline 794B-6R-CC & 795A-38X-CC & 796B-10R-CC & 797B-17H-CC & \\
\hline 794B-10R-CC & $795 \mathrm{~A}-39 \mathrm{X}-\mathrm{CC}$ & $796 \mathrm{~B}-11 \mathrm{R}-1,74-75 \mathrm{~cm}$ & $797 \mathrm{~B}-18 \mathrm{H}-1,28-29 \mathrm{~cm}$ & \\
\hline
\end{tabular}


APPENDIX B (continued).

\begin{tabular}{|c|c|c|c|}
\hline Site 794 & Site 795 & Site 796 & Site 797 \\
\hline Hole 794B & Hole 795B & Hole 796B & Hole 797B \\
\hline $794 \mathrm{~B}-11 \mathrm{R}-1,38-39 \mathrm{~cm}$ & 795B-1R-1, $40-41 \mathrm{~cm}$ & 796B-11R-2, $74-75 \mathrm{~cm}$ & $797 \mathrm{~B}-18 \mathrm{H}-5,28-29 \mathrm{~cm}$ \\
\hline 794B-11R-CC & $7958-1 \mathrm{R}-2,40-41 \mathrm{~cm}$ & 796B-11R-CC & $797 \mathrm{~B}-18 \mathrm{H}-\mathrm{CC}$ \\
\hline 794B-13R-1, $61-62 \mathrm{~cm}$ & 795B-1R-CC & $796 \mathrm{~B}-12 \mathrm{~A}-1,97-98 \mathrm{~cm}$ & $797 \mathrm{~B}-19 \mathrm{H}-1,28-29 \mathrm{~cm}$ \\
\hline 794B-13R-2, $111-112 \mathrm{~cm}$ & 795B-2R-CC & 796B-12R-3, 58-59 cm & $797 \mathrm{~B}-19 \mathrm{H}-4,28-29 \mathrm{~cm}$ \\
\hline 794B-13R-3, 79-80 cm & 795B-3R-CC & 796B-12R-CC & 797B-19H-CC \\
\hline 7948-14R-1, $108-109 \mathrm{~cm}$ & 795B-4R-CC & 796B-13R-CC & $797 \mathrm{~B}-2 \mathrm{OH}-5,27-28 \mathrm{~cm}$ \\
\hline $794 \mathrm{~B}-14 \mathrm{R}-2,100-102 \mathrm{~cm}$ & 795B-5R-CC & 796B-14R-1, $117-118 \mathrm{~cm}$ & 797B-20H-CC \\
\hline 794B-14R-CC & 795B-6R-CC & 796B-14R-CC & $797 \mathrm{~B}-21 \mathrm{X}-2,28-29 \mathrm{~cm}$ \\
\hline 794B-15R-1, 86-87 cm & 795B-7R, CC & 796B-15R-1, $119-120 \mathrm{~cm}$ & $797 \mathrm{~B}-21 \mathrm{X}-5,28-29 \mathrm{~cm}$ \\
\hline 794B-15R-2, $77-78 \mathrm{~cm}$ & 795B-8R-CC & 796B-15R-2, 100-101 cm & 797B-21X-CC \\
\hline 794B-15R-CC & 795B-9R-CC & 796B-15R-CC & $7978-22 X-2,28-29 \mathrm{~cm}$ \\
\hline 794B-16R-1, 34-35 cm & 795B-10R-2, $113-114 \mathrm{~cm}$ & 796B-16R-CC & $797 \mathrm{~B}-22 \mathrm{X}-5,28-29 \mathrm{~cm}$ \\
\hline 794B-16R-CC & 795B-10R-CC & 796B-17R-CC $(2-3 \mathrm{~cm})$ & 797B-22X-CC \\
\hline 794B-17R-1, $60-61 \mathrm{~cm}$ & 795B-11R-CC & 796B-17R-CC & $797 \mathrm{~B}-23 \mathrm{X}-2,28-29 \mathrm{~cm}$ \\
\hline 794B-17R-CC & 795B-12R-1, 56-57 cm & 796B-18R-1, $45-46 \mathrm{~cm}$ & $7978-23 X-5,28-29 \mathrm{~cm}$ \\
\hline 794B-18R-CC & 795B-12R-3, 91-92 cm & 796B-18R-4, $45-46 \mathrm{~cm}$ & 797B-23X-CC \\
\hline 794B-19R-CC & 795B-12R-CC & 796B-18R-CC & $797 \mathrm{~B}-24 \mathrm{X}-2,28-29 \mathrm{~cm}$ \\
\hline 794B-20R-3, 79-80 cm & 795B-13 R-CC & 796B-19R-1, 16-17 cm & $797 \mathrm{~B}-24 \mathrm{X}-5,27-28 \mathrm{~cm}$ \\
\hline 794B-20R-CC & 795B-14R-1, $27-28 \mathrm{~cm}$ & 796B-19R-CC & 797B-24X-CC \\
\hline $794 \mathrm{~B}-21 \mathrm{R}-4,117-118 \mathrm{~cm}$ & $7958-14 R-3,24-25 \mathrm{~cm}$ & 796B-20R-1, $68-69 \mathrm{~cm}$ & $797 \mathrm{~B}-25 \mathrm{X}-2,27-28 \mathrm{~cm}$ \\
\hline 794B-21R-CC & 795B-14R-CC & 796B-20R-CC & $797 \mathrm{~B}-25 \mathrm{X}-5,27-28 \mathrm{~cm}$ \\
\hline $794 \mathrm{~B}-22 \mathrm{R}-4,117-118 \mathrm{~cm}$ & 795B-15R-1, $38-39 \mathrm{~cm}$ & 796B-21R-CC & $797 \mathrm{~B}-25 \mathrm{X}-6,27-28 \mathrm{~cm}$ \\
\hline 794B-24R-1, $39-40 \mathrm{~cm}$ & 795B-15R-2, $41-42 \mathrm{~cm}$ & 796B-22R-1, 44-45 cm & $797 \mathrm{~B}-25 \mathrm{X}-\mathrm{CC}$ \\
\hline 794B-24R-2, $145-146 \mathrm{~cm}$ & 795B-15R-CC & 796B-22R-CC & $7978-26 X-2,27-28 \mathrm{~cm}$ \\
\hline 794B-24R-3, 36-37 cm & 795B-16R-CC & 796B-24R-CC & $797 \mathrm{~B}-26 \mathrm{X}-5,27-28 \mathrm{~cm}$ \\
\hline 794B-24R-3, 56-57 cm & 795B-17A-CC & 796B-26R-1, $124-125 \mathrm{~cm}$ & 797B-26X-CC \\
\hline 794B-24R-4. 85-86 cm & 795B-18R-2, $53-54 \mathrm{~cm}$ & 796B-26R-2, 66-67 cm & 797B-27X-2, $28-29 \mathrm{~cm}$ \\
\hline 794B-24R-5, $138-139 \mathrm{~cm}$ & 795B-18R-4, $52-53 \mathrm{~cm}$ & 796B-27R-1, 86-87 cm & $797 \mathrm{~B}-27 \mathrm{X}-5,27-28 \mathrm{~cm}$ \\
\hline 794B-24R-CC & 795B-18R-CC & 796B-28R-1, $147-148 \mathrm{~cm}$ & 797B-27X-CC \\
\hline 794B-25R-1, $17 \cdot 18 \mathrm{~cm}$ & 795B-19R-2, $52-53 \mathrm{~cm}$ & 796B-28R-CC & $797 \mathrm{~B}-28 \mathrm{X}-2,28-29 \mathrm{~cm}$ \\
\hline 794B-25R-1, $39-40 \mathrm{~cm}$ & 795B-19R-4, 53-54 cm & 796B-29R-1, $134-135 \mathrm{~cm}$ & $797 \mathrm{~B}-28 \mathrm{X}-4,28-29 \mathrm{~cm}$ \\
\hline 794B-25R-CC & 795B-19R-CC & 796B-29R-2, $117-118 \mathrm{~cm}$ & 797B-28X-CC \\
\hline 794B-26R-1, 120-121 cm & 795B-20R-CC & 796B-29R-CC & 797B-29X-CC \\
\hline 794B-26R-2, 67-68 cm & 795B-21R-CC & 796B-30R-1, $139-140 \mathrm{~cm}$ & $797 \mathrm{~B}-30 \mathrm{X}-2,27-28 \mathrm{~cm}$ \\
\hline 794B-26R-2, 75-77 cm & 795B-22R-CC & 796B-30R-2, $117-118 \mathrm{~cm}$ & $797 \mathrm{~B}-30 \mathrm{X}-4,27-28 \mathrm{~cm}$ \\
\hline \multirow[t]{21}{*}{ 794B-26R-CC } & 795B-23R-CC & 796B-30R-3, 100-101 cm & $797 \mathrm{~B}-30 \mathrm{X}-5,27-28 \mathrm{~cm}$ \\
\hline & 795B-24R-CC & 796B-31R-1, $68-69 \mathrm{~cm}$ & 797B-30X-CC \\
\hline & 795B-25R-2, $139-140 \mathrm{~cm}$ & $796 \mathrm{~B}-31 \mathrm{R}-1,72-73 \mathrm{~cm}$ & $797 \mathrm{~B}-31 \mathrm{X}-2,26-27 \mathrm{~cm}$ \\
\hline & 795B-26R-2, $29-30 \mathrm{~cm}$ & 796B-31R-2, 61-62 cm & $797 \mathrm{~B}-31 \mathrm{X}-4,27-28 \mathrm{~cm}$ \\
\hline & 795B-27R-1, $46-47 \mathrm{~cm}$ & 796B-31R-CC & 7978-31X-CC \\
\hline & 795B-28R-CC & 796B-32R-1, 80-81 cm & $797 \mathrm{~B}-32 \mathrm{X}-2,24-25 \mathrm{~cm}$ \\
\hline & 795B-29R-1, $41-42 \mathrm{~cm}$ & 796B-32R-4, 130-131 cm & $797 \mathrm{~B}-32 X-4,28-29 \mathrm{~cm}$ \\
\hline & 795B-29R-CC & 796B-32R-4, $135-136 \mathrm{~cm}$ & 797B-32X-CC \\
\hline & 795B-30R-1, 41-42 cm & 796B-32R-4,143-144 cm & $797 \mathrm{~B}-33 \mathrm{X}-2,24-25 \mathrm{~cm}$ \\
\hline & 795B-30R-3, $41-42 \mathrm{~cm}$ & 796B-32R-5, $25-26 \mathrm{~cm}$ & $797 \mathrm{~B}-33 \mathrm{X}-4,27-28 \mathrm{~cm}$ \\
\hline & $795 \mathrm{~B}-30 \mathrm{R}-5,40-41 \mathrm{~cm}$ & 796B-32A-CC & 797B-33X-CC \\
\hline & 795B-30R-CC & 796B-34R-3, $15-16 \mathrm{~cm}$ & $797 \mathrm{~B}-34 \mathrm{X}-2,24-25 \mathrm{~cm}$ \\
\hline & 795B-31R-1, $141-142 \mathrm{~cm}$ & & $797 \mathrm{~B}-34 \mathrm{X}-4,27-28 \mathrm{~cm}$ \\
\hline & $795 B-31 R-3,42-43 \mathrm{~cm}$ & & $7978-34 X-5,129-130 \mathrm{~cm}$ \\
\hline & 795B-31R-CC & & $797 \mathrm{~B}-34 \mathrm{X}-5,145-146 \mathrm{~cm}$ \\
\hline & 795B-32R-3, 36-37 cm & & 797B-34X-CC \\
\hline & 795B-32R-3, 39-40 cm & & $797 \mathrm{~B}-35 \mathrm{X}-2,24-25 \mathrm{~cm}$ \\
\hline & 795B-32R-4, 60-61 cm & & $797 \mathrm{~B}-35 \mathrm{X}-4,24-25 \mathrm{~cm}$ \\
\hline & 795B-32R-CC & & 797B-35X-CC \\
\hline & 795B-33ค-1, $75-76 \mathrm{~cm}$ & & 797B-36X-CC \\
\hline & 795B-33R-CC & & $797 B-37 X-2,21-22 \mathrm{~cm}$ \\
\hline
\end{tabular}

